\title{
The Benefits of Internationalization for State-owned enterprises
}

DOI:

10.1002/gsj. 1138

Document Version

Accepted author manuscript

Link to publication record in Manchester Research Explorer

\section{Citation for published version (APA):}

Benito, G. R. G., Rygh, A., \& Lunnan, R. (2016). The Benefits of Internationalization for State-owned enterprises. Global Strategy Journal. https://doi.org/10.1002/gsj.1138

\section{Published in:}

Global Strategy Journal

\section{Citing this paper}

Please note that where the full-text provided on Manchester Research Explorer is the Author Accepted Manuscript or Proof version this may differ from the final Published version. If citing, it is advised that you check and use the publisher's definitive version.

\section{General rights}

Copyright and moral rights for the publications made accessible in the Research Explorer are retained by the authors and/or other copyright owners and it is a condition of accessing publications that users recognise and abide by the legal requirements associated with these rights.

\section{Takedown policy}

If you believe that this document breaches copyright please refer to the University of Manchester's Takedown Procedures [http://man.ac.uk/04Y6Bo] or contact uml.scholarlycommunications@manchester.ac.uk providing relevant details, so we can investigate your claim.

\section{OPEN ACCESS}




\section{THE BENEFITS OF INTERNATIONALIZATION FOR STATE-OWNED ENTERPRISES}

Running head: The Benefits of Internationalization for State-Owned Enterprises

\section{GABRIEL R.G. BENITO,$^{1 *}$ ASMUND RYGH, ${ }^{2}$ and RANDI LUNNAN ${ }^{1}$}

${ }^{1}$ BI Norwegian Business School, Oslo, Norway

${ }^{2}$ Alliance Manchester Business School, Manchester, U.K.

Keywords: internationalization-performance relationship; state ownership; listed firms; Norway

*Correspondence to: Gabriel R.G. Benito, BI Norwegian Business School, Nydalsveien 37, 0484 Oslo, Norway. E-mail: gabriel.r.g.benito@bi.no

Plain language summary: We investigate whether listed state-owned enterprises (SOEs) benefit more from internationalization than listed private enterprises. We argue that SOEs have a greater scope for benefitting from internationalization due to their previous domestic focus and because of government-related firm-specific advantages they can utilize for their internationalization. In listed SOEs, these factors may matter more than non-economic objectives and corporate governance deficiencies that could reduce SOEs' economic benefits from internationalization. Empirical analysis on a sample of listed Norwegian firms provides modest support for the hypotheses. There is no indication that state ownership reduces the benefits of internationalization.

Technical summary: We consider state ownership as a moderator of the relationship between internationalization and performance in listed firms, developing theoretical arguments on the scope for benefits from internationalization, corporate governance, and government-related firm-specific advantages. We propose hypotheses on a positive moderation effect from state ownership overall and on more positive effects in majority stateowned enterprises (SOEs) than in minority SOEs, on more positive effects in SOEs previously part of the government administration, and on more positive effects from market-seeking internationalization than from efficiency or resource-seeking internationalization. Panel data analyses considering listed Norwegian firms (2000 to 2010) provide modest support for the hypotheses. Copyright (C) 2016 Strategic Management Society.

This article has been accepted for publication and undergone full peer review but has not been through the copyediting, typesetting, pagination and proofreading process which may lead to differences between this version and the Version of Record. Please cite this article as doi: $10.1002 / g s j .1138$ 


\section{INTRODUCTION}

Recent studies describe a reinvention of state capitalism (Bruton et al., 2015; Musacchio, Lazzarini, and Aguilera, 2015) based on state-owned enterprises (SOEs), where the state shares ownership with private owners (the state being either a majority or a minority owner) that are publicly listed and that are focusing more on the international arena (Cuervo-Cazurra et al., 2014). Many of these SOEs are highly profitable and internationally competitive, on par with private enterprises (Musacchio et al., 2015). The increasing internationalization of SOEs has spurred a number of recent studies in international business (IB) on the strategies of SOEs in terms of foreign location and entry mode choices (e.g., Cui and Jiang, 2012; Knutsen, Rygh, and Hveem, 2011; Meyer et al., 2014). We still know little, however, about what specific benefits SOEs get from their international activities and about whether and how these benefits differ from those enjoyed by privately owned enterprises (POEs). This study presents theoretical arguments, as well as empirical evidence using data on Norwegian listed firms (2000 to 2010), on these questions.

Based on the study of POEs, IB research has used a variety of theoretical perspectives to argue for a generally positive relationship between internationalization and economic performance (I/P relationship). Contractor (2012) reviewed eight types of arguments found in the IB literature, including exploiting scale and scope economies, diversifying risk, reducing costs, and accessing knowledge from and learning about the international environment, among others. In a related but largely separate literature in international economics, a similar 'learning-by-exporting' hypothesis proposes that contact with international buyers and competitors produces learning effects and that international competition forces firms to be more efficient and stimulates innovation (Greenaway and Kneller, 2007; Wagner, 2007, 2012). 
The interest in considering how firms with different types of ownership can gain from internationalization is highlighted by the fact that after three decades of research in IB, results on the I/P relationship remain inconclusive (Contractor, 2012; Verbeke and Forootan, 2012). It has been recognized that internationalization also entails costs, including increasing coordination, information, and monitoring costs (Contractor, 2012). Empirical studies alternatively report positive, negative, and insignificant relationships; as well as a variety of nonlinear relationships motivated theoretically by changes in the relationship between benefits and costs as internationalization progresses from low to high levels. ${ }^{1}$ This inconclusiveness has led some researchers to question the notion of a general I/P relationship (whether linear or more complex) itself and instead look for factors that increase or constrain the ability of firms to benefit from internationalization.

Bowen (2007) claims empirical I/P studies in IB have so far not paid sufficient attention to how differences between firms in terms of firm-specific advantages (FSAs) and performance may imply sample selection, omitted variable, and simultaneity biases. ${ }^{2}$ Based on transaction cost theory, Hennart $(2007,2011)$ argues that what matters for performance is not multinationality per se, but whether the firm's integration decisions, whether domestic or cross-border, are appropriate. In particular, deviation from a firm's economically optimal degree of multinationality would imply a negative I/P relationship. Powell (2014) finds empirical support for Hennart's ideas and calls for research on factors determining whether firms deviate from their optimal multinationality following a transaction cost logic. To explain a sometimes observed positive I/P relationship, Hennart (2011) speculates that successful highly internationalized firms could differ from other firms in terms of managerial and governance characteristics. For example, some companies may have managers who are

\footnotetext{
${ }^{1}$ A similar inconclusiveness regarding learning-by-exporting is found in the international economics literature (Wagner, 2007, 2012).

${ }^{2}$ In contrast, international economists take it as 'something of a stylized fact that ex ante productivity determines the choice of whether or not to export' (Greenaway and Kneller, 2007: F135).
} 
more internationally experienced and, therefore, better able to work out and implement a strategy aligned with an optimal foreign footprint. Or their governance in terms of ownership structure and the identities of owners and board members could encompass and bring superior international competence and outlook into play. Again, this suggests differences between firms matter.

We argue that state ownership may affect both firms' scope for benefitting from internationalization as well as their ability to do so. SOEs may indeed have particularly much to gain from internationalization, to the extent that a sheltered domestic position and a focus on domestic goals have meant little exposure to international competition and impulses. SOEs' actual ability to gain from internationalization will depend on factors such as their corporate governance as well as their unique FSAs. We argue the new breed of publicly listed SOEs are better equipped to benefit from internationalization given that the non-economic objectives and corporate governance deficiencies often believed to characterize SOEs are less relevant, while these SOEs may still possess particular government-related FSAs, including financial and political FSAs.

Although this context provides only a partial picture of the effects of internationalization on SOEs, studying publicly listed SOEs is highly appropriate to assess the economic benefits of SOEs from internationalization, as listed SOEs have predominantly commercial objectives, providing a common yardstick for measuring them against POEs. To study the benefits of internationalization for SOEs more generally, including non-listed SOEs (as well as their owner governments), one may need to look beyond purely economic measures, which is an important topic for future research.

Our arguments lead to hypotheses on a positive moderation effect from state ownership on the I/P relationship, implying that listed SOEs benefit more than listed POEs. Furthermore, we develop hypotheses on the effects of majority versus minority state 
ownership and on the effects of the origins of the SOEs as either government administration units or POEs. Our hypotheses are tested on a sample of Norwegian listed firms over the period 2000 to 2010 . Overall, doing analyses that also account for endogeneity issues and influential observations, our evidence provides modest support for the hypotheses. There is no indication that state ownership reduces the ability of Norwegian listed firms to benefit from internationalization.

This article presents the first comprehensive theoretical and empirical investigation of the benefits that listed SOEs may reap from internationalization. Although results are not fully robust, some analyses indicate that SOEs are better able than POEs to benefit from internationalization. More broadly, by showing the relevance of corporate ownership, our results also pertain to the emerging firm heterogeneity perspective, especially regarding corporate governance, on the benefits and costs of internationalization (Kirca et al., 2012; Wang, 2014). The most closely related study is Xiao et al. (2013), which reports that incorporated firms (including state-owned ones), POEs, and foreign-owned firms benefit more from internationalization than a group of 'conventional locals' including (unincorporated) state-owned firms and collective enterprises. Xiao et al. (2013) also find centralized state governance to positively moderate the I/P relationship. However, they do not isolate an effect of state ownership, unlike our study. Rather, they show that listed SOEs are more likely to gain than are other SOEs.

We next present in detail our theory and hypotheses. We then describe our methods, data, and the results from the empirical analysis. The article ends with a discussion and conclusions. 


\section{THEORY AND HYPOTHESES}

By ownership, we refer to the holding of equity in a company. There are several dimensions of ownership, but ownership studies usually distinguish between ownership structure, i.e., whether ownership is dispersed or concentrated, and ownership identity, for example whether equity owners are private persons or institutions like banks or the government, or whether they are domestic or foreign (Thomsen and Pedersen, 2000). Economically, ownership matters because of cash flow rights and decision rights. Ownership concentration is closely linked to the ability and motivation of owners to control the behavior of managers, although it also has a bearing on the relationships among owners in a firm (Becht, Bolton, and Röell, 2003). Owners of different identities may have different preferences in terms of the firm's strategies and different implications for governance structures.

An extensively studied ownership identity is state ownership. A major focus of the state ownership literature has been the relative economic performance of SOEs and POEs. It is empirically well established that state ownership of firms, in general, is associated with lower economic performance than is private ownership (e.g., Goldeng, Grünfeld, and Benito, 2008; Megginson and Netter, 2001). Suggested explanations come in two broad categories: non-economic objectives and corporate governance failures. ${ }^{3}$ First, theoretical justifications for state ownership include addressing various kinds of market failures and achieving social goals such as preserving employment (Megginson and Netter, 2001), all of which may come at the expense of the firm's own economic performance.

Second, various corporate governance issues are associated with the multilayered delegation chain from voters via politicians and bureaucrats to SOE managers (Tirole, 1994). Though direct state ownership shares are often large, state ownership is ultimately dispersed

\footnotetext{
${ }^{3}$ It is useful to distinguish between these two explanations, although they are related. For instance, they are related in that non-economic objectives may make corporate governance more difficult by reducing the measurability of SOE performance, which may, in turn, prevent the use of high-powered (i.e., performancesensitive) reward structures (Tirole, 1994).
}

This article is protected by copyright. All rights reserved. 
across all citizens, implying strong control rights but weak cash flow rights for politicians (Shleifer and Vishny, 1997). Politicians and bureaucrats are mainly motivated by reelection, reputation, and/or ideology rather than personal economic benefits (Ludvigsen, 2010). Multiple and unclear objectives might also make effective governance more difficult. Additionally, standard corporate governance mechanisms such as takeovers, valuation through share prices, and sales of shares are deactivated in SOEs. Such corporate governance issues expectedly lead to greater SOE manager discretion to pursue personal goals (e.g., empire building) rather than value maximization. SOEs may also, in some cases, be used by politicians and bureaucrats to extract personal benefits (Estrin et al., 2016).

This image of SOEs is traditionally associated with full state ownership. However, a subset of the state ownership literature adds important nuances by considering the implications of introducing private co-ownership in SOEs, and even publicly listing SOEs. Hence, current research is moving away from the traditional dichotomy between state owned and private to acknowledge the hybrid nature of these firms (Bruton et al., 2015). Both noneconomic motives and corporate governance deficiencies are likely to be less important in publicly listed SOEs. Public listing generally reflects a government commitment to have SOEs focus more on commercial outcomes, and it subjects SOEs to additional corporate governance requirements, for instance in terms of reporting and equal treatment of shareholders (Bøhren and Ødegaard, 2001). Public listing of SOEs will also mean the introduction of partial private ownership and the existence of share prices, improving information about the firm's performance and introducing some degree of market discipline, as well as strengthening the managerial labor market (Gupta, 2005). Partial private ownership is, thus, argued to alleviate many corporate governance problems traditionally associated with SOEs. Empirically, partial private ownership has been found to improve performance (Gupta, 
2005), although mixed ownership SOEs still tend to lag behind fully POEs in terms of economic performance (Boardman and Vining, 1989).

Thus, there may be important differences between wholly SOEs and partially SOEs. Among partially SOEs, there may be further important differences between majority and minority SOEs (Musacchio et al., 2015). In the former category, while private owners enter, the state retains control given its majority share. In the latter, in contrast, private owners are in a majority, and the firm is supported by state minority capital. Although in some cases there may be residual interference by the state, such firms are more similar to wholly POEs, and non-economic motives and corporate governance issues associated with state ownership are reduced further. Minority SOEs still may enjoy some state support, but are likely to face harder budget constraints than do wholly SOEs and majority SOEs (Musacchio et al., 2015).

\section{Benefits and costs of internationalization for listed state-owned enterprises}

As noted, Contractor (2012) reviewed benefits of internationalization including exploiting scale and scope economies, diversifying risk, reducing costs, and accessing knowledge and learning about the international environment, among others. The related 'learning-byexporting' hypothesis in international economics emphasizes that contact with international buyers and competitors produces learning effects and that international competition forces firms to be more efficient (reducing so-called 'X-inefficiency,' cf. Andersson and Lööf, 2009; Leibenstein, 1966) and stimulates innovation (Greenaway and Kneller, 2007; Wagner, 2007, 2012).

A priori, these effects should all be just as relevant for SOEs as for POEs. In fact, one could argue the scope for benefits such as learning and international competition reducing Xinefficiency is even greater in SOEs, which may help reduce any gap between SOEs and POEs. In their study of Norwegian firms, Goldeng et al. (2008) find state ownership reduces 
performance even after controlling for competition, but competition seems to have a less negative effect on SOEs. One explanation the authors offer is that SOEs start from a lower performance level and, hence, have a greater scope from learning from competitors and for reducing X-inefficiency. ${ }^{4}$ A similar effect may occur when SOEs enter international competition. If SOEs had relatively sheltered positions in their home markets, competitive interaction in the international market may be particularly beneficial, as it stimulates innovation and increases efficiency in SOEs. ${ }^{5}$ Similarly, if SOEs traditionally focused on their home markets and for that reason were less exposed to international influences, learning effects from internationalization may be particularly strong for SOEs. ${ }^{6}$

While SOEs may have greater potential benefits from internationalization, a question is to what extent SOEs are able to reap these benefits (while controlling costs). Indeed, some authors suggested that the logic itself of state ownership is difficult to reconcile with that of multinationality and that the existence of multinational SOEs is even somewhat paradoxical (Anastassopoulos, Blanc, and Dussauge, 1987). The previous I/P literature implicitly had in mind POEs, focused on value maximization, but non-economic objectives could imply that economic performance takes a back seat. Usually, non-economic goals of SOEs will relate to the domestic context, implying SOEs are domestically focused and less likely to internationalize in the first place (Benito, Lunnan, and Tomassen, 2011; Majocchi and Strange, 2012; Mazzolini, 1979). Government owners have traditionally been skeptical about SOE international expansion, although they may be more positive about SOE exports than about SOE international production (Mazzolini, 1979). When SOEs do go abroad, this may not be motivated primarily by improving economic performance, but rather by home government strategic (e.g., securing natural resources) or diplomatic goals. Governments may

\footnotetext{
${ }^{4}$ Although SOEs might also have a lesser ability to learn.

${ }^{5}$ To this, one may add Tirole's (1994) argument that competition for SOEs may provide the government with useful information and benchmarks for assessing SOE performance.

${ }^{6}$ If in their international activities SOEs are also relieved from the government non-economic objectives they pursue domestically and can focus on business considerations, learning effects may be even stronger.
} 
accept substantial losses in SOE international activities, at least in the short run, to ensure such goals are achieved (Anastassopoulos et al., 1987; Mazzolini, 1979). If so, the moderating effect of state ownership is likely to be negative.

Furthermore, inadequate corporate governance could reduce the pressure on SOEs to choose the most profitable internationalization strategies, hence affecting the I/P relationship (Wang, 2014; Xiao et al., 2013). Hennart $(2007,2011)$ argued that performance is not a function of multinationality as such, but rather of the appropriateness of the multitude of integration ('make or buy') decisions made by firms, some of which could be cross-border. Hennart (2011) reasons that firms with foreign footprints that deviate from their optimum could experience an adverse effect on performance. While transaction cost theory postulates that economically inefficient governance forms tend to be selected out (Williamson, 1995), if firms are insulated from this mechanism due to inadequate corporate governance and soft budget constraints (Kornai, 1979), non-value-maximizing behavior may persist. This is especially relevant for state owners that may not be concerned primarily about economic performance, at least in the short term. Again, the implication would be a negative moderation effect from state ownership.

As we have argued, however, in the case of modern publicly listed SOEs with partial private ownership (Musacchio et al., 2015), both non-economic goals and corporate governance deficiencies may be of less importance. Such SOEs have more or less clear mandates from their government owners to pursue economic results, and they face additional pressure from private co-owners to do so (Bruton et al., 2015). Although in some cases they may still be influenced by their home governments to pursue additional goals, in such SOEs, it is more likely that international strategies are motivated mainly by their effect on the financial bottom line. 
Nonetheless, listed SOEs retain links with their home states that may represent unique FSAs for their internationalization. Government owners may still have some incentives to present softer budget constraints (Kornai, 1979) toward SOEs, implying financial FSAs, for instance, in the form of direct subsidies, cheap loans, or preferential treatment for government purchases (Anastassopoulos et al., 1987). However, SOE financial FSAs need not reflect soft budget constraints, but could arise also due to the state owner being highly diversified and having, in principle, a long time horizon, reducing pressure on SOEs to deliver immediate economic results (Knutsen et al., 2011; Rudy, Miller, and Wang, 2016; Vernon, 1979). The state may allow SOEs to undertake projects that are unprofitable for many years, but that may be more profitable in the long term. SOEs may also be able to undertake larger projects (Cuervo-Cazurra et al., 2014). Governments may also make available other types of government-related resources that help the SOEs succeed internationally, especially in challenging environments. In particular, SOEs may possess political FSAs unavailable to POEs. Such political FSAs could include political connections giving privileged access to the diplomatic apparatus, information about foreign environments and bilateral trade and investment negotiations, and political support more generally (e.g., Anastassopoulos et al., 1987; Knutsen et al., 2011; Lawton and Rajwani, 2011; Mazzolini, 1979). They could also include political experience and knowledge leading to, for instance, a better understanding of political processes and the motivations of politicians.

If a government is committed to having SOEs focus on commercial goals (which, for instance, will bring income to the state and give politicians a positive image), it may be willing to relinquish control to private co-owners and the SOE's managers; it may still be in the interest of the government to support the SOE by providing financial and political FSAs, if such FSAs allow the SOE to improve its performance. 
Combining arguments on the possibly greater scope for benefits from internationalization for listed SOEs with arguments on the reduced role of non-economic motives and corporate governance deficiencies, as well as arguments on their unique government-related FSAs, we see why listed SOEs may benefit more than their private counterparts from internationalization. Listed SOEs' focus on commercial results and comonitoring by private owners will increase the propensity of SOEs to choose valuemaximizing projects. Further, government-related resources may enable SOEs to take particular advantage of international exposure. With financial FSAs, SOEs may benefit from a longer learning period than POEs, without being forced out of business (Goldeng et al., 2008; Tan and Peng, 2003), and political FSAs may allow them to undertake projects that POEs find too risky (Cui and Jiang, 2012; Knutsen et al., 2011). The combination of these three arguments leads us to the following general hypothesis:

Hypothesis 1 (H1): State ownership positively moderates the internationalizationperformance relationship for listed companies.

While this general hypothesis is plausible, we next offer a set of more fine-grained hypotheses related to the type of listed SOE and the type of internationalization in question.

\section{Majority-owned versus minority-owned listed SOEs}

As we have noted, there are potentially important differences between majority SOEs, in which the state retains control, and minority SOEs, in which private owners are in a majority. First, the scope for benefits from internationalization is likely to be greater in majority SOEs since they are assumed to lag more behind wholly POEs in terms of efficiency than minority SOEs that are run almost like POEs (Musacchio et al., 2015). Second, however, majority SOEs could also be less able than minority SOEs to benefit from internationalization due to a greater influence of non-economic objectives imposed by the owner state as well as corporate governance issues associated with state control. Third, majority SOEs likely have better 
access to various government-related FSAs to support their internationalization than do minority SOEs. Such access is likely to be positively associated with the extent of government control rights (i.e., with a higher ownership share) and, hence, with the likelihood that the SOE will align with politicians' interests. On balance, we hypothesize that the first and third effects dominate over the second so that:

Hypothesis 2 (H2): Majority SOEs benefit more from internationalization than do minority SOEs.

\section{SOEs' administrative heritage}

As noted by Anastassopoulos et al. (1987), multinational SOEs have very different histories. Some are SOEs originally created for domestic purposes that have later gone international. Another important category is formerly POEs, where the state has taken an ownership share. One would expect these two categories of SOEs to differ in their internationalization (Cuervo-Cazurra et al., 2014) and to experience different benefits and costs of internationalization. In particular, SOEs that were previously part of the government administration were predominantly inward looking (focusing on the domestic context) and less exposed to international influences. Their potential benefits from internationalization will be particularly high. These SOEs may also have an 'inherited' culture and routines from their previous role as administrative units that imply weaker capabilities in spotting international opportunities than POEs in general (Anastassopoulos et al., 1987; Mazzolini, 1979); but, it is also likely that they have been able to build up a strong base of FSAs from their previously sheltered position that they can exploit internationally (Collins, 1986). It is also likely that they receive particularly extensive government support. Thus, we hypothesize:

Hypothesis 3 (H3): SOEs with a past as governmental administrative institutions benefit more from internationalization than do SOEs that were originally established as private firms. 


\section{Benefits for SOEs from different forms of internationalization}

Different types of internationalization may involve different types of benefits and costs, including different types of learning effects (Silva, Afonso, and Africano, 2012). Foreign sales reflect a predominantly market-seeking form of internationalization, involving learning about foreign markets or gaining technological knowledge from foreign buyers (for instance, through product specifications and technical assistance). Still, Hashai et al. (2010) argue that production FDI promotes specific types of learning achieved through close supervision, monitoring, and learning-by-doing. Since such learning takes place within a common organizational structure, it is probably different than the one achieved through market modes such as exporting or outsourcing.

Given their nature, we expect that SOEs will lag behind POEs in terms of capabilities such as marketing, while they may be on par with POEs in terms of pure technical efficiency. Hence, we hypothesize:

\section{Hypothesis 4 (H4): SOEs benefit relatively more from market-seeking internationalization than other types of internationalization (i.e., resource, asset, or efficiency seeking) compared to POEs.}

\section{DATA AND METHODS}

To test the hypotheses, we conduct regression analyses on a panel dataset comprising 30 of the largest publicly listed Norwegian firms over the period 2000 to $2010 .^{7}$ The research context is particularly well suited for a study of the benefits for SOEs from internationalization. First, Norway is a relatively small, but advanced open economy, and most companies of some size and significance will seriously consider internationalization as an important part of their strategies. Yet, internationalization levels still vary considerably across companies and time. Second, Norway features a mix of SOEs and POEs in a broad

\footnotetext{
${ }^{7}$ Some data are missing for a few companies for certain years, meaning the number of observations included in each analysis varied slightly.
}

This article is protected by copyright. All rights reserved. 
range of sectors (Goldeng et al., 2008), and this is also the case for Norwegian companies listed on the Oslo Stock Exchange and among Norwegian foreign investors (Knutsen et al., 2011).

The publicly listed SOEs in the Norwegian data have different origins. Some of them were previously part of the government administration before being corporatized and deregulated. Such SOEs include Telenor, which was originally the state telephone operator but was listed in 2000 and is now a significant international telecom company. Another example is Statoil, which was created in 1972 as Norway's national oil company. It was partially privatized and listed in 2001 , having by then already undertaken international investments. ${ }^{8}$ Other SOEs started out as private companies before becoming state owned. Some examples are Norsk Hydro, in which the state took a significant ownership share after World War II, and Aker Solutions, in which the state bought an equity stake in 2007 in order to secure long-term strategic Norwegian ownership. Finally, many small state ownership positions (less than 10\%) are indirect via the Norwegian Pension Fund-Norway (a smaller sovereign wealth fund investing mainly domestically, unlike the much larger and better known Norwegian Pension Fund-Global).

According to official Norwegian government ownership policy documents, the listed SOEs all have predominantly commercial goals. Non-economic goals mainly consist of an explicit requirement of the SOEs to retain HQs functions in Norway, which is intended to promote long-term national ownership and development and maintenance of competences nationally. Despite being state owned, these companies have generally been allowed to internationalize, and they often have been encouraged to do so (e.g., Austvik, 2012). Partial private ownership in all these companies implies that certain additional corporate governance provisions are present. Norway focuses on professionalism in SOE governance and has a

\footnotetext{
${ }^{8}$ Statoil plays an important role in Norway's oil-based economy and, as such, one might be concerned that it has a large influence on our results. However, auxiliary analyses dropping Statoil from the estimation sample produce very similar results.
} 
capable bureaucracy, both of which help reduce the liabilities of state ownership (Estrin et al., 2016). The guidelines for state ownership emphasize equal treatment of shareholders and transparency regarding state ownership policies. Like other owners, the state must exercise its ownership influence via the companies' general assemblies.

Our dataset consists of the major listed companies, provided the companies had history dating back to at least 2000 and available data could be identified on variables of interest to this study. ${ }^{9}$ The dataset comprises companies in the resource, manufacturing, and services sectors, thus it covers a range of industries. The information has been collected from companies' annual reports, company websites, company directories, and information resources such as Factiva and Kompass. The companies in the dataset are generally quite large companies: they had, on average, 7,827 employees and almost NOK 31 billion in annual sales in 2010. They are also highly international, with an average foreign sales ratio of 70 percent (see Table 1). Nevertheless, there is substantial variation in the data in the sense that we have companies with no international activity at some point as well as companies with complete internationalization.

Moreover, there is notable variation in the state ownership share, with companies featuring no or low state ownership shares as well as companies with high state shares. For the sample as a whole, the average state ownership share ranged from 15.5 percent (in 2007) to 18.3 percent (in 2002). There is also variation in the state share of several SOEs over time. For instance, Cermaq's state ownership share was 80 percent in 2000, but it dropped to 43.5 percent in 2006. The only firm-year with full state ownership was Statoil in 2000, whose state share stood at 70 percent in 2010 following partial privatization (starting in 2001). There are

\footnotetext{
${ }^{9}$ While this approach might raise some concerns about survivor bias, the population of large Norwegian firms has been remarkably stable in the previous two decades (Benito et al., 2002; Grøgaard, Gioia, and Benito, 2013). The dataset comprises the following 30 companies: Aker, Aker Solutions, Atea, Cermaq, DNO International, EDB Business Partner, Ekornes, Farstad Shipping, Hafslund, Kongsberg Automotive, Kongsberg Gruppen, Lerøy Seafood Group, Marine Harvest Group, Norsk Hydro, Norske Skogindustrier, Odfjell, Orkla, Petroleum Geo-Services, Prosafe, Rieber \& Søn, Schibsted, Scana Industrier, Statoil, Stolt-Nielsen, Telenor, TGS-NOPEC Geophysical Company, Tomra Systems, TTS Marine, Veidekke, and Yara International.
} 
examples of companies with increased state ownership during the period as well as companies with decreased state ownership. Hence, there is quite a bit of variation in the state ownership share to use in the analyses, although fewer SOEs crossed key ownership thresholds such as 50 percent during the sample period.

\section{Dependent variable: performance}

We use both Tobin's $Q$ — the ratio of market-to-book value of a company's assets—and profitability measures — return on assets $(R O A)$ and return on sales $(R O S)$ - to capture performance. Different performance measures have different strengths and biases. It is difficult to find a performance measure that would be completely neutral across industries, firms, and time. For example, an emphasis on intangibles inflates Tobin's $Q$ and $R O A$ measures, whereas $R O S$ could be partially driven by the maturity of an industry. We attenuate the likelihood of biased findings by using three different measures of performance (Verbeke and Forootan, 2012).

\section{Main independent variables: Ownership and internationalization}

Our main measure of state ownership identity is the percentage of equity held by the Norwegian government. This measure captures the difference between the listed SOEs in terms of their relationship with the state. However, when testing Hypothesis 2, we instead use dummy variables for majority or minority state ownership, capturing nonlinear (threshold) effects of state ownership. When testing Hypothesis 3, we use dummies for SOEs with a past in the government administration and for SOEs with other origins. All analyses use an omitted baseline category of wholly POEs. 
To capture the degree of internationalization, we use both the ratio of foreign sales to total sales $(F S T S)$ and the ratio of foreign employment to total employment $(F E T E) .{ }^{10}$ Considering both these measures is useful because they capture somewhat different internationalization motives (cf. Verbeke and Forootan, 2012). FSTS is arguably primarily a measure of market-seeking internationalization ('how much is sold abroad'), while FETE is more closely related to efficiency-, resource-, or asset-seeking internationalization ('how much is produced abroad') (cf. Dunning and Lundan, 2008). We utilize this when testing Hypothesis 4 on benefits from different forms of internationalization.

\section{Control variables}

We control for various company and industry characteristics that may affect internationalization and/or performance. First, we control for ownership concentration, which the corporate governance literature tells us affects the motivation or ability of owners to monitor performance (e.g., Becht et al., 2003), measured as the combined percentage of equity held by the five largest owners. A second control is foreign ownership, measured as the percentage of equity held by non-Norwegians. Foreign corporate owners may transfer to subsidiaries FSAs such as superior technologies, valuable brand names, and organizational capabilities, although foreign-owned firms may be less advantaged vis-à-vis domestically based MNEs (Pfaffermayr and Bellak, 2000).

We also control for company size, measured by number of employees, transformed using the natural logarithm. Corporate diversification is captured by a dummy given the value of ' 1 ' if the companies were conglomerates and ' 0 ' otherwise: the classification was based on Grøgaard et al. (2013), identifying companies that operated in unrelated industries in terms of their ISIC codes. We also include dummies capturing whether the main sector of the

\footnotetext{
${ }^{10}$ Note that in the case of foreign-owned firms, the foreign sales and employees that are counted are only those of the firm registered in Norway, not other sales or employees that the foreign owner may have worldwide.
} 
company was industrial or services, with the omitted baseline being the resource sector. Another dummy indicates the existence of an industry cluster in Norway in the companies' main industries, which could positively affect firm performance. Based on previous cluster studies in Norway (see Reve and Jakobsen, 2000), the following sectors were coded as clusters: fisheries and aquaculture (ISIC code 05), oil and gas and related services (ISIC codes 11 and 74), yards (ISIC code 35), shipping (ISIC code 61), and telecommunications and IT (ISIC codes 64 and 72).

Unfortunately, adequate (time-variant) measures of FSAs (such as intangible assets or R\&D and marketing expenses) were not available for most of the firm-years in our data. Instead, robustness tests use a country-level industry R\&D intensity measure $(R \& D$ expenditures divided by industry sales) from the OECD. ${ }^{11}$ This variable is quite fine-grained inasmuch as it is measured at the country level (Norway), rather than at the global level. The downside is that the variable is available only until 2008 for Norway and is missing for certain sectors, thereby substantially reducing the number of cases available for these regressions. For this reason, the variable is not included in our main analyses, but robustness tests show the results for our main variables of interest are similar when including it.

Finally, year dummies capture time-specific effects (e.g., the 2008 financial crisis). ${ }^{12}$ Tables 1 and 2 provide descriptive statistics and a correlation matrix, respectively.

[Insert Tables 1 and 2 about here]

\section{ESTIMATION AND RESULTS}

The moderation effect is tested by including an interaction term between internationalization and state ownership (Brambor, Clark, and Golder, 2006); a positive (negative) coefficient on

\footnotetext{
${ }^{11}$ See https://stats.oecd.org/Index.aspx?DataSetCode=STANINDICATORS.

${ }^{12} \mathrm{~A}$ joint test of the significance of the year dummies confirmed that they should be included in all models.
} 
the interaction term between state ownership and internationalization implies positive (negative) moderation.

We must account for the fact that observations from one firm are related, while adequately utilizing variation in the data. Our main analyses use a random effects (RE) specification with robust standard errors clustered at the company. Although RE can also be used for time-invariant or slow-moving variables, as noted earlier, there is substantial variation in both the ownership share and internationalization for many companies. ${ }^{13}$ An alternative method for analyzing panel type data, ordinary least squares with panel corrected standard errors (OLS-PCSE), is often used in political science for datasets where the number of time periods is relatively large compared to the number of units (Beck and Katz, 1995). Our dataset arguably has those characteristics, and we also estimated our model with OLSPCSE (results available on request). Our most robust results remained in these tests.

The results for $\mathrm{H} 1$ using the random effects specification are shown in Table 3 (with the first three columns using FSTS as the internationalization measure and the last three using FETE as the internationalization measure).

[Insert Table 3 about here]

Consistent with H1, state ownership has a strongly statistically significant positive moderation effect for ROA and FSTS (Model 2 in Table 3) and for ROS and FETE (Model 6 in Table 3) (both at the $1 \%$ level). However, as the interaction coefficients in the other models are statistically insignificant overall our results provide limited support for the

\footnotetext{
${ }^{13}$ Initial Breusch-Pagan and Hausman tests respectively suggested that while unobserved effects are relevant (and, hence, random effects is preferred over standard OLS), correlation between the unobserved effect and the explanatory variables is not a problem and, hence, we can use the more statistically efficient random effects rather than fixed effects (Kennedy, 2003). Also, while using fixed effects implies that time-invariant variables (e.g., sector) are subsumed under the firm fixed effects, relatively temporally stable variables (e.g., state ownership) can make the use of fixed effects problematic (Beck and Katz, 2001).
} 
hypothesis that state ownership positively moderates the I/P relationship. In particular, we find no effects on the market-based performance measure (Models 1 and 4), suggesting investors do not value internationalization of SOEs more or less than that of POEs. ${ }^{14}$

Although we hesitate to attach strong confidence to the exact effect sizes due to the potential impact of endogeneity (as discussed in footnote 20, methodological studies have found that interaction terms are much less affected by endogeneity than the 'direct' effects), the results demonstrate that listed Norwegian POEs generally experience a negative performance effect from internationalization, while SOEs with substantial state ownership enjoy a positive effect (see Figure 1 for a display of average marginal effects and Appendix Table A1 for complete results). Following Yang, Martins, and Driffield (2013), in Model 2, a 10 percentage point increase in $F S T S$ implies a $-0.51 \times 0.10=-0.051$ reduction in $R O A$, which is not negligible since the average $R O A$ in the sample is 0.14 . Increasing state ownership by 10 percent implies an improvement in the average marginal effect of roughly 0.069. At, for instance, 10 percent state ownership, the estimated coefficient is -0.439 , implying a 10 percentage points increase in FSTS would reduce ROA by -0.044 . At 50 percent state ownership, this effect is reduced to -0.016 . However, not until state ownership reaches about 80 percent is the estimated effect actually positive (0.004). Similarly, in Model 6, a wholly POE is estimated to experience a reduction in $R O S$ of $-0.14 \times 0.10=-0.014$, which can be compared to a mean ROS of 0.11 in the sample when increasing FETE by 10 percentage points. Increasing state ownership by 10 percent implies an improvement in the average marginal effect of about 0.036 . Reaching 40 percent state ownership, the effect is positive but relatively small, at $0.0032 \times 0.10=0.0003$. At 70 percent state ownership, the estimate is $0.1101 \times 0.10=0.011^{15} 16$

\footnotetext{
${ }^{14}$ However, additional analysis excluding suspected outliers do suggest a positive effect from state ownership, as discussed later.

${ }^{15}$ To give a rough calculation of actual monetary amounts, we can multiply the coefficient of 0.011 with the average (median) amount of total sales of NOK 30 billion in the sample (cf. Guest, 2009). This gives an increase
} 
[Insert Figure 1 about here]

While our baseline analysis operationalized state ownership using the state ownership percentage, it may be that threshold levels for state ownership matter. Musacchio et al. (2015) argued that there are important differences between majority SOEs and minority SOEs.

Hence, we create dummies for each of these two categories. In an analysis on the full sample simultaneously entering both categories and their interactions with internationalization (Table 4), we find majority SOEs display a positive moderation effect in Model 2, while minority SOEs do not, thus supporting H2. In Model 6, they both display a positive moderation effect for the full sample. In Model 3, we find a positive moderation effect for both categories that was not reflected in the analyses using the ownership share (possibly due to nonlinear effects of state ownership). Overall, support for $\mathrm{H} 2$ is limited, as the only difference supporting $\mathrm{H} 2$ is found in Model 2, as confirmed by the significant Wald test $(p=0.0008)$ for differences in the interaction coefficients for the two SOE categories. ${ }^{17}$

The test for H3 has a very similar setup, but it uses dummies for SOEs with administrative heritage and for those without. The results (Table 5) follow the same pattern as for H2: the only significant difference between the SOE categories is found in Model 2 for

of about NOK 338 million or about $\$ 40$ million (NOK 82 million or about \$10 million) from a 10 percentage point increase in FETE for a firm with 70 percent state ownership. A wholly POE would have a loss of a roughly similar magnitude. In Model 2, corresponding calculations using the average (median) amount of assets for the samples firms suggest a gain of NOK 162 million or about $\$ 19$ million (NOK 36 million or about $\$ 4$ million).

${ }^{16}$ For the sake of completeness, as shown in Figure 1, Models 1 (Tobin's Q, FSTS) and 4 (Tobin's Q, FETE) estimates are invariant to state ownership, whereas for Models 3 (ROA, FSTS) and 5 (ROS, FETE) estimates turn positive at 70 percent and 40 percent state ownership, respectively. However, none of these effects are significant.

${ }^{17}$ The same conclusions follow when testing $\mathrm{H} 2$ in an alternative way by running a subsample analysis on firmyears with positive state ownership and entering only the majority ownership dummy and its interaction with internationalization. In this analysis, the omitted baseline is minority SOEs. The only statistically significant difference is found in Model 2, where the interaction term with majority state ownership is positive (implying greater benefits for majority SOEs), reflecting the results from the full sample analysis. 
H1, as confirmed by the significant Wald test $(p=0.0113) .{ }^{18}$ This is probably largely due to the fact that in the Norwegian case, there is substantial overlap in the firm-years between majority state ownership and administrative heritage (which need not be the case in general).

Finally, H4 suggested SOEs benefit more from market-seeking internationalization (measured by FSTS) than from internationalization having other motives (measured by FETE), given that SOEs are likely to lag particularly behind private enterprises in terms of marketing and related capabilities. Taking these results together, we find mixed support for this hypothesis, as there are also indications that SOEs benefit from other forms of internationalization. However, as shown in additional analyses described next, the effects for FSTS are more robust.

[Insert Tables 4 and 5 about here]

\section{ADDITIONAL ANALYSES AND ROBUSTNESS CHECKS}

Finally, we performed several additional analyses (results available on request) to check the robustness of our main results. First, FSAs other than financial and political ones could play a role. Unfortunately, relevant (time-variant) measures of FSAs (such as intangible assets or R\&D and marketing expenses) were not available for a sufficient number of observations. However, we were able to include a time-variant industry-level $\mathrm{R} \& \mathrm{D}$ measure for Norwegian firms for the years 2000 to 2008 , for most of the industries. Including this variable in our baseline models, the results are very similar, although statistical significance is marginally weakened, which could be partly due to the loss of many observations.

Second, influential observations could bias the results since the Norwegian context of listed firms features a number of large SOEs. Checking the Cook's distance measure (Cook's

\footnotetext{
${ }^{18}$ Again, subsample analysis on firm-years with state ownership contrasting the two SOE categories gives the same results.
}

This article is protected by copyright. All rights reserved. 
D) from a set of OLS regressions, we find that all observations have a Cook's D value far below the often suggested threshold of 1 . Applying the stricter threshold of $4 / \mathrm{N}$ (about 0.01 ) and omitting observations with a higher Cook's D value than this from our random effects regressions, we find the result in Model 2 still holds $(p=0.001)$, while the one in Model 6 is now lost. But, we find a new positively significant interaction effect $(p=0.026)$ in Model 4 for the market-based performance measure, in this case suggesting the lack of results for the full sample reflects influential observations.

Finally, a positive I/P relationship may be caused by self-selection of betterperforming firms into internationalization rather than because internationalization as such benefits firms (Bernard and Jensen, 1999; Bowen, 2007; Verbeke and Forootan, 2012). Better performance for firms that initiated exporting than for those that did not does not necessarily imply that exporting improves performance since these best-performing firms would increase their performance more anyway (e.g., Wagner, 2002). A related issue is simultaneity bias, as high performance could provide slack financial resources to overcome fixed costs of exporting and/or FDI (Verbeke and Forootan, 2012). There is also a potential for both selection and endogeneity of ownership. For instance, the state might take ownership in poorly performing firms in order to safeguard employment (or privatizing well-performing SOEs may be easier) (Megginson and Netter, 2001).

While panel data techniques account for time-invariant firm-specific characteristics (e.g., unobserved managerial capabilities) causing both high performance and a high level of internationalization, they do not solve potential endogeneity issues related to reverse causality and time-variant omitted variables. ${ }^{19}$ Also, while recent studies suggest endogeneity is much

\footnotetext{
${ }^{19} \mathrm{We}$ also tested specifications lagging internationalization variables by one year. Besides ensuring temporal precedence, lagging these variables also seems appropriate when arguing for learning effects (Silva et al., 2012). The results were similar, although statistical significance was sometimes weakened.
} 
less problematic when the interest is in interaction terms, this cannot be taken for granted. ${ }^{20}$ Hence, as an additional check on our results, we implement generalized method of moments (GMM) analyses, generating internal instruments for the potentially endogeneous variables using lagged variables in the panel. ${ }^{21}$ This approach has gained popularity since good external instruments are not always available (Roodman, 2009a); in our case, we need to find instruments not only for internationalization, but also for the ownership-related variables. We implement GMM using the Stata ${ }^{\circledR}$ xtabond2 module (Roodman, 2009a). The time-invariant variables drop out in these analyses that remove unit-specific effects. We treat both internationalization variables (FSTS or FETE) and the three ownership variables as potentially endogeneous. We follow Roodman's (2009a, 2009b) recommendations of including time dummies in order to avoid contemporaneous correlation and of using the orthogonal deviation transformation (Arellano and Bover, 1995) in our panel with gaps in order to maximize sample size. The two-step version of GMM implements the Windmeijer (2005) standard error correction. While GMM is commonly used for relatively small samples, we must pay attention to the risk of overinstrumentation. To keep the instrument count approximately to the 'rule of thumb' of not exceeding the number of units (30 in our case), we use an approach based on principal component analysis (PCA) (Bontempi and Mammi, 2012) combined with, alternatively (to check robustness), the methods of limiting the number of lags used (to the second and the third lags) or of 'collapsing' the instrument matrix.

The results show the positive moderation effect for state ownership for $R O S$ measuring internationalization by FSTS found in baseline Model 2 in Table 3 is retained

\footnotetext{
${ }^{20}$ A simulation study by Withers, Certo, and Semadeni (2014) reported that OLS gives unbiased coefficient estimates for interactions, even when the independent and/or moderator variables are endogenous. In contrast, endogeneity was found to bias the coefficient estimates for the main effects of the components of the interactions. Endogeneity is apparently 'partialed out' through the main effects, leaving the interaction term unaffected. Bun and Harrison (2014) provide a mathematical treatment and also argue that in some cases one may proceed as if the interaction term was exogenous. Omitted variables is generally less problematic than simultaneity.

${ }^{21}$ GMM-type approaches are used in the learning-by-exporting literature (e.g., Andersson and Lööf, 2009) as well as in the state ownership (Gupta, 2005) literature. The alternative approach of matching (e.g., Golovko and Valentini, 2014; Wagner, 2002) is not viable here due to the relatively small sample.
} 
when PCA is combined with limiting lags. ${ }^{22}$ However, the results are lost when using the method of collapsing the instrument matrix. Nevertheless, our main results are largely reproduced even in a type of analysis that is very different from our baseline RE analysis (e.g., using fixed effects instead of random effects and instrumenting five different explanatory variables).

\section{DISCUSSION AND CONCLUSIONS}

A notable element in the recent reinvention of state capitalism has been the greater focus of SOEs on international activities (Cuervo-Cazurra et al., 2014; He, Eden, and Hitt, 2016; Musacchio et al., 2015; Rudy et al., 2016). This article has explored theoretically and empirically the benefits SOEs get from internationalization and how these benefits differ from those of POEs. The main argument has been that on one hand SOEs have a comparatively larger potential to gain from internationalization, given their traditionally domestic focus and often a sheltered domestic market position. On the other hand, SOEs' ability to do so depends on the impact of any non-economic objectives and corporate governance deficiencies, as well as their particular FSAs. We have explored this in the context of listed SOEs where goals are predominantly commercial (allowing a more meaningful comparison with POEs) and where partial private ownership as well as corporate governance requirements mitigate traditional SOE corporate governance issues.

Overall, our analyses using a sample of Norwegian listed firms provide only limited support for the idea that SOEs benefit more from internationalization than POEs. The positive results are most consistent for market-seeking internationalization (measured by the ratio of

\footnotetext{
${ }^{22}$ All specifications pass the test for no second-order autocorrelation as well as both the Sargan test (insensitive to the number of instruments, but not robust to heteroskedasticity) and the Hansen J-test (robust to heteroskedasticity, but weakened by many instruments) (Roodman, 2009a) for instrument exogeneity. In the former, the instrument count is about 30 and sometimes as high as 33. Some of these analyses also feature high Hansen J-statistics, which may indicate overinstrumentation. In the latter, the instrument count is usually about 20 , and J-statistics are lower (but never near significant at 10\%).
} 
foreign sales to total sales), and there are also hints that they are stronger for majority SOEs than for minority SOEs and for SOEs that were previously part of the government administration. Overall, a reasonable interpretation of the results is that SOEs originally created to focus on domestic public policy goals reap greater net benefits from internationalization and that they above all learn to adapt to (foreign) markets through their internationalization. Moreover, majority SOEs may have both a larger scope for benefits from internationalization and enjoy more government-related FSAs than minority SOEs, outweighing their plausibly more substantive non-economic objectives and corporate governance issues associated with government majority control.

Although the hypotheses receive only modest support overall, it is also worth spelling out what our results do not suggest. Given our context of mainly commercially oriented listed SOEs, a negative moderation effect would suggest that either residual state intervention or remaining corporate governance deficiencies limit SOEs' economic benefits from internationalization compared to POEs. While this might seem intuitive given traditional claims about state ownership having a negative performance effect, there is no indication of this in our results. Only for the market-based performance measures and in a couple of GMM specifications is the interaction coefficient sometimes negative, but never significant. In the other cases, the interaction coefficient has a positive sign and is often statistically significant. Overall, there is no indication that state ownership in Norwegian listed firms limits the benefits from internationalization, and there are suggestive indications of the opposite.

\section{Contributions}

To the growing literature on SOE internationalization, we add original theoretical arguments and empirical evidence on the performance of SOEs in the international context, an issue that has received much less attention (but see Miroudot and Ragoussis (2013) on SOE and POE 
subsidaries) than differences between SOEs and POEs in terms of internationalization levels (e.g., Majocchi and Strange, 2012), location choices (e.g., Knutsen et al., 2011), and foreign market entry choices (e.g., Meyer et al., 2014). However, studies of SOE internationalization also pertain to the state ownership literature more broadly (Cuervo-Cazurra et al., 2014). Our results inform the ongoing debate on the relative importance of ownership versus the environment (e.g., in terms of competition and regulation) in explaining the generally weaker economic performance of SOEs (Bartel and Harrison, 2005; Goldeng et al., 2008; Megginson and Netter, 2001). Some of our analyses indicate that internationalization may indeed be a strategy for improving SOE performance. Research exploring the economic behavior and performance of SOEs in an international environment, including the present study and Miroudot and Ragoussis (2013), holds promise to help our understanding of scope and boundary conditions regarding the main theories of state ownership. Today's many internationally competitive SOEs may indeed be of a different breed than yesterday's often badly run and inefficient SOEs (Cuervo-Cazurra et al., 2014).

Finally, this study contributes to the literature on internationalization and performance by investigating how state ownership affects the ability of firms to benefit from internationalization, based on arguments on how state ownership affects corporate governance and the FSAs of firms. As such, this study supports the view that 'the power, influence and expertise of different stakeholders within corporate governance have a strong influence on strategic decision-making, in general, and internationalization strategies, in particular' (Jackson and Strange, 2008, 3). Our arguments also concern the effects of ownership indirectly through the development of FSAs, linking up to resource-based theory, on which basis Douma, George, and Kabir $(2006,640)$ noted that 'considerable resource heterogeneity [may exist] among various shareholder categories.' This goes beyond the traditional agency perspective, which assumes financial resources are the only type of 
resource transferred from owners to firm (cf. Shleifer and Vishny, 1997). Our study, therefore, suggests an interesting extension of the resource-based theory based on the fact that some government-related FSAs might indeed represent resources that are valuable, rare, inimitable, and non-substitutable (Barney, 1991) and can be exploited internationally.

\section{Limitations and avenues for further research}

Our data from Norway should be particularly well suited for the purpose of examining effects of state ownership. One downside is that the small size of the Norwegian economy leaves us with a somewhat limited, yet fairly heterogeneous, dataset. While our research context is useful in many respects, it also suggests limits to generalizability. A negative moderation effect of state ownership would be more plausible when considering non-listed SOEs. Such SOEs are both more likely to focus on non-economic objectives and to experience traditional SOE corporate governance issues, meaning that their ability (and even motivation) to benefit economically from internationalization is weaker than for listed SOEs. Future research should, therefore, investigate whether and how listed and non-listed SOEs differ in this respect.

Although listed SOEs are a global phenomenon (Bruton et al., 2015), further research on other countries is imperative since the adequacy of corporate governance, even of listed SOEs, depends on the home country's institutions (Estrin et al., 2016). An interesting possibility is that an additional benefit from internationalization could arise for SOEs from very weak corporate governance contexts that are exposed to stronger corporate governance regimes internationally (cf. Jackson and Strange, 2008).

While demonstrating the relevance of ownership, this study provides just one part of the broader picture. Further research should consider more general samples including nonlisted firms and firms from other countries, as well as additional owner categories (e.g., 
institutional owners or family owners). Future research could also consider the development of specific FSAs in firms with different ownership through internationalization (e.g., innovation outcomes as in Golovko and Valentini, 2014), although many relevant FSAs (e.g., managerial capabilities) are inherently difficult to measure. Finally, while we measure two aspects of internationalization, more fine-grained measures are desirable.

\section{Managerial and policy implications}

With these limitations in mind, several implications can be derived. The main managerial implications concern the utilization of ownership-related advantages. Overall, our study suggests that in listed companies, state ownership is not a hindrance for benefitting from internationalization, with some analyses suggesting it may be an advantage. Nevertheless, one should not presume the interests of a listed SOE and the owner government will always coincide, and managers of listed SOEs may need to counterbalance the economic interests of private owners with possible additional requirements imposed by the government in particular situations. As proposed by Anastassopoulos et al. (1987), harnessing governmentrelated benefits for SOE internationalization may still require skilled management.

A policy implication for owner-governments seems to be that encouraging and supporting the internationalization of SOEs may imply economic benefits. An important question for future research, however, is to what extent SOE international activities come at the expense of any domestic public policy goals. Politicians have often been skeptical of SOE foreign operations that could come at the expense of employment or activity in the SOE at home (Mazzolini, 1979). Little is known about the relationship of SOEs' international activities to their domestic activities. In principle, the relationship could be one of substitution, whereby SOE resources spent abroad limit activities at home. Alternatively, activities could be complementary. In some industries, technology and market structure may 
imply that foreign activities are essential for any firm, whether state owned or private (Florio, 2013). Additional revenues from foreign markets could also help finance domestic SOE activities, including activities with non-economic objectives. Research on these issues will provide a fuller picture of the effects of SOE internationalization.

\section{ACKNOWLEDGEMENTS}

We thank the anonymous reviewers and GSJ Editor Torben Pedersen for their constructive advice and Sjoerd Beugelsdijk, Alvaro Cuervo-Cazurra, Alessandra Luzzi, and Amir Sasson for helpful comments and suggestions on previous versions of this article. We are also grateful for the feedback received in seminars at Copenhagen Business School and BI Norwegian Business School and from participants at the 2013 Vaasa International Business Conference (Vaasa, Finland), the 2013 Annual SMS Conference (Atlanta), the 2013 Annual EIBA Conference (Bremen, Germany), and the 2015 AIB Annual Meeting (Bangalore, India). The usual disclaimer applies.

\section{REFERENCES}

Anastassopoulos J-P, Blanc G, Dussauge P. 1987. State-Owned Multinationals. Wiley: New York.

Andersson M, Lööf H. 2009. Learning-by-exporting revisited: the role of intensity and persistence. Scandinavian Journal of Economics 111(4): 893-916.

Arellano M, Bover O. 1995. Another look at the instrumental variable estimation of errorcomponents models. Journal of Econometrics 68(1): 29-51.

Austvik OG. 2012. Landlord and entrepreneur: the shifting roles of the state in Norwegian oil and gas policy. Governance 25(2): 315-334. 
Barney JB. 1991. Firm resources and sustained competitive advantage. Journal of Management 17(1): 99-120.

Bartel AP, Harrison AE. 2005. Ownership versus environment: disentangling the sources of public sector inefficiency. Review of Economics and Statistics 87(1): 135-147.

Becht M, Bolton P, Röell A. 2003. Corporate governance and control. In Handbook of the Economics of Finance, Constantinides GM, Harris M, Stulz R (eds). Elsevier: Amsterdam, The Netherlands: 1-109.

Beck N, Katz JN. 1995. What to do (and not to do) with time-series cross-section data. American Political Science Review 89(3): 634-647.

Beck N, Katz JN. 2001. Throwing out the baby with the bath water: a comment on Green, Kim, and Yoon. International Organization 55(2): 487-495.

Benito GRG, Larimo J, Narula R, Pedersen T. 2002. Multinational enterprises from small economies: internationalization patterns of large companies from Denmark, Finland, and Norway. International Studies of Management \& Organization 32(1): 57-78.

Benito GRG, Lunnan R, Tomassen S. 2011. Distant encounters of the third kind: multinational companies locating divisional headquarters abroad. Journal of Management Studies 48(2): 373-394.

Bernard AB, Jensen JB. 1999. Exceptional exporter performance: cause, effect, or both? Journal of International Economics 47(1): 1-25.

Boardman AE, Vining AR. 1989. Ownership and performance in competitive environments: a comparison of the performance of private, mixed, and state-owned enterprises. Journal of Law \& Economics 32: 1-33.

Bøhren $\emptyset, \emptyset$ degaard BA. 2001. Patterns of corporate ownership: insights from a unique data set. Nordic Journal of Political Economy 27: 55-86. 
Bontempi ME, Mammi I. 2012. A strategy to reduce the count of moment conditions in panel data GMM. Working paper, Social Science Research Network, Rochester, NY. Available at: http://dx.doi.org/10.2139/ssrn.2140799 (accessed 20 August 2016).

Bowen HP. 2007. The empirics of multinationality and performance. Research in Global Strategic Management 13: 113-142.

Brambor T, Clark WR, Golder M. 2006. Understanding interaction models: improving empirical analyses. Political Analysis 14(1): 63-82.

Bruton GD, Peng MW, Ahlstrom D, Stan C, Xu K. 2015. State-owned enterprises around the world as hybrid organizations. Academy of Management Perspectives 29(1): 92-114.

Bun MJ, Harrison TD. 2014. OLS and IV estimation of regression models including endogenous interaction terms. Working paper, University of Amsterdam, Amsterdam, The Netherlands.

Collins P. 1986. Multinational state-owned enterprises and the eclectic theory. In Multinational Corporations and State-Owned Enterprises: A New Challenge in International Business, Negandhi AR, Thomas H, Rao KLK (eds). JAI Press: London, U.K.; 43-58.

Contractor FJ. 2012. Why do multinational firms exist? A theory note about the effect of multinational expansion on performance and recent methodological critiques. Global Strategy Journal 2(4): 318-331.

Cuervo-Cazurra A, Inkpen A, Musacchio A, Ramaswamy K. 2014. Governments as owners: state-owned multinational companies. Journal of International Business Studies 45(8): 919-942.

Cui L, Jiang F. 2012. State ownership effect on firms' FDI ownership decisions under institutional pressure: a study of Chinese outward-investing firms. Journal of International Business Studies 43(3): 264-284. 
Douma S, George R, Kabir R. 2006. Foreign and domestic ownership, business groups, and firm performance: evidence from a large emerging market. Strategic Management Journal 27(7): 637-657.

Dunning JH, Lundan SM. 2008. Multinational Enterprises and the Global Economy. Edward Elgar Publishing: Cheltenham, U.K.

Estrin S, Meyer KE, Nielsen BB, Nielsen S. 2016. Home country institutions and the internationalization of state-owned enterprises: a cross-country analysis. Journal of World Business 51(2): 294-307.

Florio M. 2013. Rethinking on public enterprise: editorial introduction and some personal remarks on the research agenda. International Review of Applied Economics 27(2): 135149.

Goldeng E, Grünfeld LA, Benito GRG. 2008. The performance differential between private and state-owned enterprises: the roles of ownership, management, and market structure. Journal of Management Studies 45(7): 1244-1273.

Golovko E, Valentini G. 2014. Selective learning-by-exporting: firm size and product versus process innovation. Global Strategy Journal 4(3): 161-180.

Greenaway D, Kneller R. 2007. Firm heterogeneity, exporting, and foreign direct investment. Economic Journal 117(517): F134-F161.

Grøgaard B, Gioia C, Benito GRG. 2013. An empirical investigation of the role of industry factors in the internationalization patterns of firms. International Studies of Management \& Organization 43(1): 81-100.

Guest PM. 2009. The impact of board size on firm performance: evidence from the U.K. European Journal of Finance 15(4): 385-404.

Gupta N. 2005. Partial privatization and firm performance. Journal of Finance 60(2): 9871015. 
Hashai N, Asmussen CG, Benito GRG, Petersen B. 2010. Technological knowledge intensity and entry mode diversity. Management International Review 50(6): 659-681.

He X, Eden L, Hitt MA. 2016. The renaissance of state-owned multinationals. Thunderbird International Business Review 58(2): 117-129.

Hennart JF. 2007. The theoretical rationale for a multinationality-performance relationship. Management International Review 47(3): 423-452.

Hennart JF. 2011. A theoretical assessment of the empirical literature on the impact of multinationality on performance. Global Strategy Journal 1(1/2): 135-151.

Jackson G, Strange R. 2008. Why does corporate governance matter for international business? In Corporate Governance and International Business: Strategy, Performance, and Institutional Change, Strange R, Jackson G (eds). Palgrave Macmillan: Basingstoke, U.K.; 1-14.

Kennedy PE. 2003. A Guide to Econometrics (5th edn). Blackwell Publishing: Oxford, U.K.

Kirca AH, Roth K, Hult GTM, Cavusgil ST. 2012. The role of context in the multinationality-performance relationship: a meta-analytic review. Global Strategy Journal 2(2): 108-121.

Knutsen CH, Rygh A, Hveem H. 2011. Does state ownership matter? Institutions' effect on foreign direct investment revisited. Business and Politics 13(1): 1-33.

Kornai J. 1979. Resource-constrained versus demand-constrained systems. Econometrica 47(4): 801-820.

Lawton T, Rajwani T. 2011. Designing lobbying capabilities: managerial choices in unpredictable environments. European Business Review 23(2): 167-189.

Leibenstein H. 1966. Allocative efficiency vs. 'X-efficiency.' American Economic Review 56(3): 392-415. 
Ludvigsen S. 2010. State ownership and corporate governance: empirical evidence from Norway and Sweden. PhD dissertation, BI Norwegian School of Management, Oslo, Norway.

Majocchi A, Strange R. 2012. International diversification: the impact of ownership structure, the market for corporate control and board independence. Management International Review 52(6): 879-900.

Mazzolini R. 1979. Government Controlled Enterprises: International Strategic and Policy Decisions. Wiley: New York.

Megginson WL, Netter JM. 2001. From state to market: a survey of empirical studies on privatization. Journal of Economic Literature 39(2): 321-389.

Meyer KE, Ding Y, Li J, Zhang H. 2014. Overcoming distrust: how state-owned enterprises adapt their foreign entries to institutional pressures abroad. Journal of International Business Studies 45(8): 1005-1028.

Miroudot S, Ragoussis A. 2013. New actors in the international investment scenario: objectives, performance, and advantages of affiliates of state-owned enterprises and sovereign wealth funds. In Prospects in International Investment Law and Policy, Echandi R, Sauvé P (eds). World Trade Forum: Cambridge, U.K.; 51-72.

Musacchio A, Lazzarini S, Aguilera R. 2015. New varieties of state capitalism: strategic and governance implications. Academy of Management Perspectives 29(1): 115-131.

Pfaffermayr M, Bellak C. 2000. Why foreign-owned firms are different: a conceptual framework and empirical evidence for Austria. In Foreign-Owned Firms: Are they Different?, Jungnickel R (ed). Palgrave Macmillan: Basingstoke, U.K.: 13-57.

Powell KS. 2014. From M-P to MA-P: multinationality alignment and performance. Journal of International Business Studies 45(2): 211-226.

Reve T, Jakobsen EW. 2000. Et verdiskapende Norge. Universitetsforlaget: Oslo, Norway. 
Roodman D. 2009a. How to do xtabond2: an introduction to difference and system GMM in Stata. Stata Journal 9(1): 86-136.

Roodman D. 2009b. A note on the theme of too many instruments. Oxford Bulletin of Economics and Statistics 71(1): 135-158.

Rudy BC, Miller SR, Wang D. 2016. Revisiting FDI strategies and the flow of firm-specific advantages: a focus on state-owned enterprises. Global Strategy Journal 6(1): 69-78.

Shleifer A, Vishny RW. 1997. A survey of corporate governance. Journal of Finance 52(2): 737-783.

Silva A, Afonso O, Africano AP. 2012. Learning-by-exporting: what we know and what we would like to know. International Trade Journal 26(3): 255-288.

Tan J, Peng MW. 2003. Organizational slack and firm performance during economic transitions: two studies from an emerging economy. Strategic Management Journal 24(13): 1249-1263.

Thomsen S, Pedersen T. 2000. Ownership structure and economic performance in the largest European companies. Strategic Management Journal 21(6): 689-705.

Tirole J. 1994. The internal organization of government. Oxford Economic Papers 46(1): 129.

Verbeke A, Forootan MZ. 2012. How good are multinationality-performance (M-P) empirical studies? Global Strategy Journal 2(4): 332-344.

Vernon R. 1979. The international aspects of state-owned enterprises. Journal of International Business Studies 10(3): 7-15.

Wagner J. 2002. The causal effects of exports on firm size and labor productivity: first evidence from a matching approach. Economics Letters 77(2): 287-292.

Wagner J. 2007. Exports and productivity: a survey of the evidence from firm-level data. World Economy 30(1): 60-82. 
Wagner J. 2012. International trade and firm performance: a survey of empirical studies since 2006. Review of World Economics 148(2): 235-267.

Wang C-F. 2014. International diversification and firm performance: the moderating effects of corporate governance. European Journal of International Management 8(4): 415-439.

Williamson OE. 1995. Hierarchies, markets, and power in the economy: an economic perspective. Industrial and Corporate Change 4(1): 21-49.

Windmeijer F. 2005. A finite sample correction for the variance of linear efficient two-step GMM estimators. Journal of Econometrics 126(1): 25-51.

Withers MC, Certo T, Semadeni M. 2014. Examining the influence of endogeneity when testing interactions. Paper presented at the Annual Strategic Management Society Conference, Madrid, Spain.

Xiao SS, Jeong I, Moon JJ, Chung CC, Chung J. 2013. Internationalization and performance of firms in China: moderating effects of governance structure and the degree of centralized control. Journal of International Management 19(2): 118-137.

Yang Y, Martins PS, Driffield N. 2013. Multinational performance and the geography of FDI. Management International Review 53(6): 763-794. 
Model 1

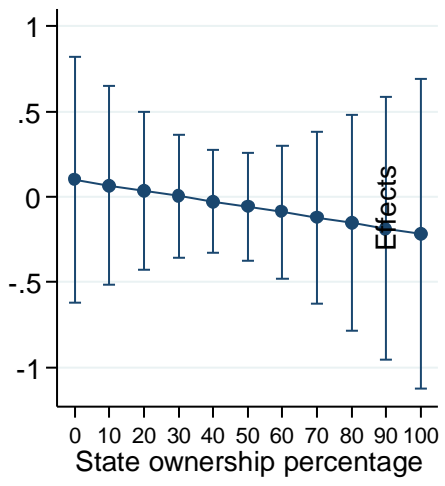

Model 4

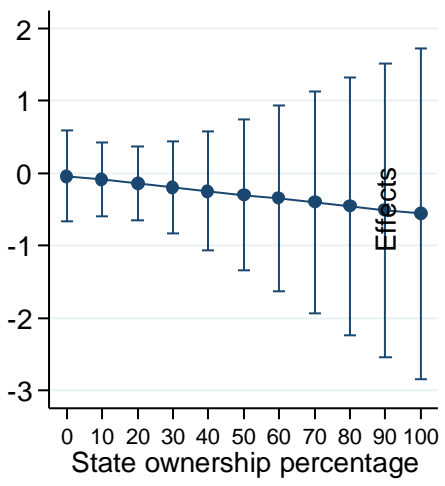

Model 2

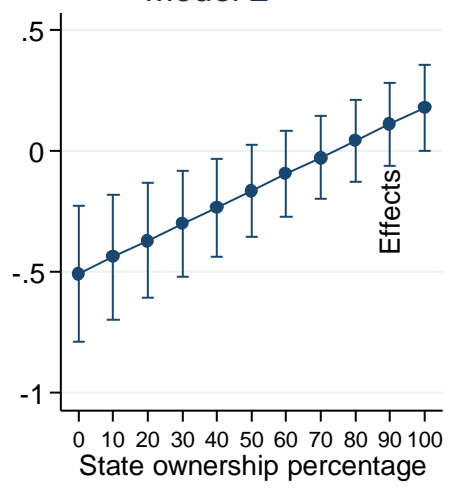

Model 5

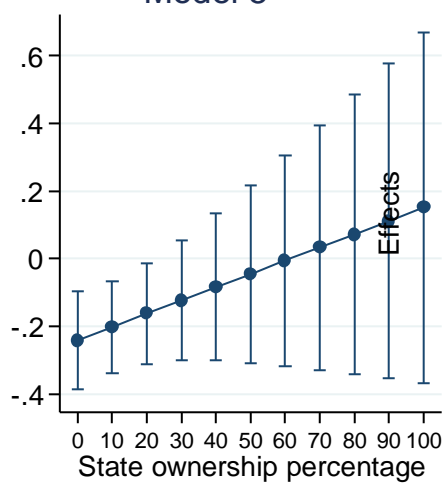

Model 3

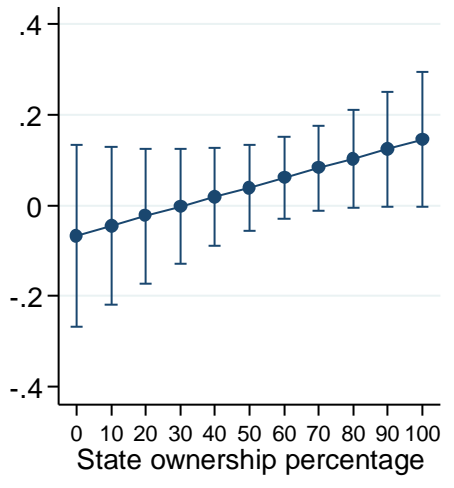

Model 6

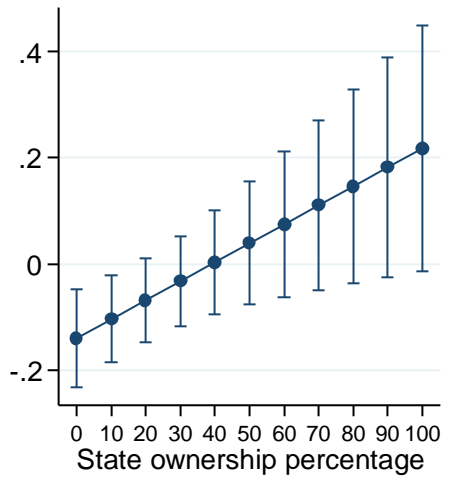

Figure 1. Average marginal effects for baseline regression models 
Table 1. Descriptive statistics

\begin{tabular}{lccccc}
\hline & Mean & St. Dev. & Min. & Median & Max. \\
\hline Tobin's Q & 0.86 & 0.87 & 0.00064 & 0.68 & 9.20 \\
ROA & 0.14 & 0.40 & -3.63 & 0.12 & 2.44 \\
ROS & 0.11 & 0.18 & -1.30 & 0.080 & 0.69 \\
Foreign sales ratio & 0.71 & 0.27 & 0 & 0.80 & 1 \\
Foreign employment ratio & 0.60 & 0.28 & 0 & 0.68 & 1 \\
State ownership & 15.9 & 22.6 & 0 & 7.00 & 100 \\
Foreign ownership & 32.8 & 23.7 & 0 & 34.4 & 87.9 \\
Ownership concentration & 54.4 & 20.8 & 16.6 & 54.8 & 100 \\
Employees & $7,894.1$ & $10,234.3$ & 29 & $3,485.5$ & 46,255 \\
Goods & 0.46 & 0.50 & 0 & 0 & 1 \\
Services & 0.33 & 0.47 & 0 & 0 & 1 \\
Cluster & 0.57 & 0.50 & 0 & 1 & 1 \\
Conglomerate & 0.12 & 0.32 & 0 & 0 & 1 \\
\hline S. & & 0.5125
\end{tabular}

Statistics are calculated for all observations with non-missing data. The table gives the figure for employees without the log-transformation used for the statistical analysis. 
Table 2. Correlation matrix for variables used in main analyses
(1)
(2)
(3)
(4) (5)
(6)
(7)
(8)
(9) (10)
(11) (12) (1

(1)

Tobin's Q

(2) ROA $\quad 0.28 \quad 1.00$

(3) ROS $\quad \underset{* * * *}{0.22} \quad \underset{* * * * *}{0.52} \quad 1.00$

(4)

Foreign

sales ratio

(5)

Foreign

$$
\begin{array}{llll}
0.11 & 0.03 & 0.07 & 1.00
\end{array}
$$

employm

ent ratio

(6) State $\quad-\quad \begin{array}{llllll}0.09 & 0.05 & - & - & 1.00\end{array}$

$\begin{array}{llll}\text { ownershi } & 0.02 & 0.25 & 0.24 \\ * * * * * * & \end{array}$

$\mathrm{p}$

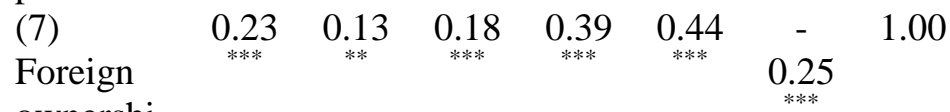

$\begin{array}{ccccc}- & - & 0.04 & 0.51 & 1.00 \\ 0.00 & 0.03 & & \end{array}$

ownershi

$\mathrm{p}$

$\begin{array}{llllllllll}\text { (8) } & - & - & - & - & - & 0.39 & - & 1.00\end{array}$

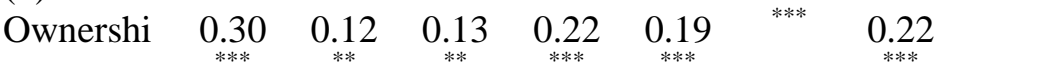

$\mathrm{p}$

concentra

tion

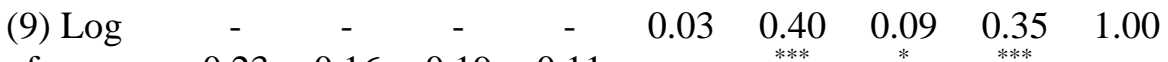

of

employee

$\mathrm{s}$

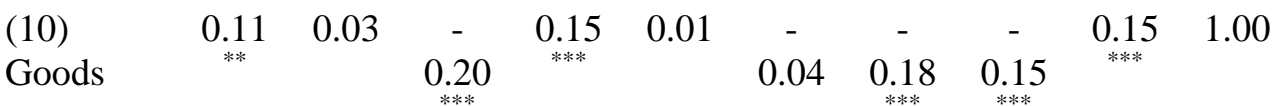

$\begin{array}{lccccccccccc}(11) & - & - & 0.18 & - & 0.29 & - & 0.33 & 0.04 & - & - & 1.00 \\ \text { Services } & 0.08 & 0.04 & & 0.06 & * * * * & 0.17 & * * * & & 0.06 & 0.66 & \end{array}$

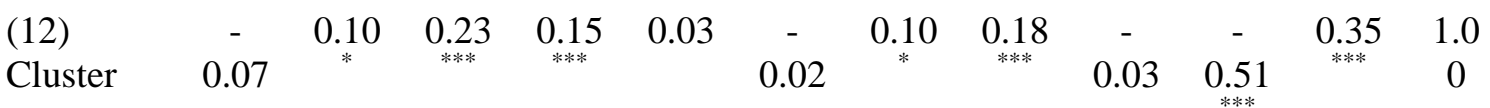

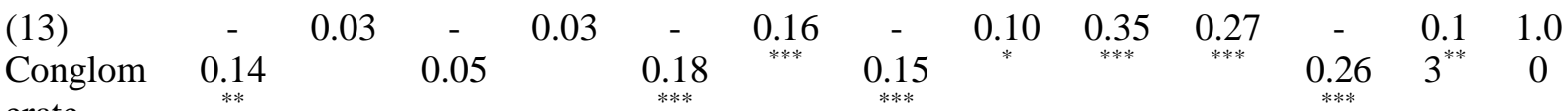
erate ${ }^{*} p<0.10,{ }^{* *} p<0.05,{ }^{* * *} p<0.01$. 
Table 3. Random effects analyses for the general Hypothesis 1

\begin{tabular}{|c|c|c|c|c|c|c|}
\hline & $\begin{array}{c}(1) \\
\text { Tobin's } \\
Q\end{array}$ & $\begin{array}{c}(2) \\
\text { ROA }\end{array}$ & $\begin{array}{l}(3) \\
\text { ROS }\end{array}$ & $\begin{array}{c}(4) \\
\text { Tobin's } \\
Q\end{array}$ & $\begin{array}{c}(5) \\
\text { ROA }\end{array}$ & $\begin{array}{c}\text { (6) } \\
\text { ROS }\end{array}$ \\
\hline Foreign sales ratio & $\begin{array}{l}0.099 \\
(0.37)\end{array}$ & $\begin{array}{l}-0.51^{* * *} \\
(0.14)\end{array}$ & $\begin{array}{l}-0.066 \\
(0.10)\end{array}$ & & & \\
\hline Foreign employment ratio & & & & $\begin{array}{l}-0.040 \\
(0.32)\end{array}$ & $\begin{array}{l}-0.24^{* * *} \\
(0.074)\end{array}$ & $\begin{array}{l}-0.14^{* * *} \\
(0.047)\end{array}$ \\
\hline State ownership & $\begin{array}{l}0.011^{* *} \\
(0.0055)\end{array}$ & $\begin{array}{l}-0.00064 \\
(0.0016)\end{array}$ & $\begin{array}{c}- \\
0.000011 \\
(0.0013)\end{array}$ & $(0.0059)$ & $(0.0015)$ & $\begin{array}{l}-0.00071 \\
(0.0011)\end{array}$ \\
\hline $\begin{array}{l}\text { State ownership } \times \text { Foreign } \\
\text { sales ratio }\end{array}$ & $\begin{array}{l}-0.0031 \\
(0.0077)\end{array}$ & $\begin{array}{l}0.0069^{* * * *} \\
(0.0014)\end{array}$ & $\begin{array}{l}0.0021 \\
(0.0015)\end{array}$ & & & \\
\hline $\begin{array}{l}\text { State ownership } \times \text { Foreign } \\
\text { employment ratio }\end{array}$ & & & & $\begin{array}{l}-0.0052 \\
(0.013)\end{array}$ & $(0.0028)$ & $\begin{array}{l}0.0036^{* * * *} \\
(0.0014)\end{array}$ \\
\hline Foreign ownership & $\begin{array}{c}0.013^{*} \\
(0.0080)\end{array}$ & $\begin{array}{l}0.0055^{* *} \\
(0.0025)\end{array}$ & $\begin{array}{c}0.0011 \\
(0.00081)\end{array}$ & $\begin{array}{c}0.013 \\
(0.0085)\end{array}$ & $\begin{array}{l}0.0047^{* *} \\
(0.0023)\end{array}$ & $\begin{array}{c}0.0012^{*} \\
(0.00069)\end{array}$ \\
\hline Ownership concentration & $\begin{array}{c}- \\
0.0079^{* * *} \\
(0.0036)\end{array}$ & $\begin{array}{c}- \\
0.000018 \\
(0.0026)\end{array}$ & $\begin{array}{c}-0.0010 \\
(0.00075)\end{array}$ & $\begin{array}{c}- \\
0.0083^{* *} \\
(0.0039)\end{array}$ & $\begin{array}{c}- \\
0.000031 \\
(0.0028)\end{array}$ & $\begin{array}{l}-0.00088 \\
(0.00080)\end{array}$ \\
\hline Log of employees & $\begin{array}{c}-0.20^{* * * *} \\
(0.064)\end{array}$ & $\begin{array}{l}-0.12^{* *} \\
(0.049)\end{array}$ & $\begin{array}{l}-0.021 \\
(0.019)\end{array}$ & $\begin{array}{l}-0.19^{* * * *} \\
(0.072)\end{array}$ & $\begin{array}{l}-0.098^{*} \\
(0.051)\end{array}$ & $\begin{array}{l}-0.017 \\
(0.020)\end{array}$ \\
\hline Goods & $\begin{array}{l}0.34^{* *} \\
(0.16)\end{array}$ & $\begin{array}{c}0.19 \\
(0.14)\end{array}$ & $\begin{array}{l}-0.0084 \\
(0.055)\end{array}$ & $\begin{array}{l}0.36^{* *} \\
(0.17)\end{array}$ & $\begin{array}{c}0.17 \\
(0.12)\end{array}$ & $\begin{array}{l}0.0066 \\
(0.053)\end{array}$ \\
\hline Services & $\begin{array}{l}-0.13 \\
(0.22)\end{array}$ & $\begin{array}{l}-0.056 \\
(0.16)\end{array}$ & $\begin{array}{c}0.022 \\
(0.062)\end{array}$ & $\begin{array}{l}-0.12 \\
(0.25)\end{array}$ & $\begin{array}{c}0.0098 \\
(0.16)\end{array}$ & $\begin{array}{c}0.047 \\
(0.065)\end{array}$ \\
\hline Cluster & $\begin{array}{l}0.072 \\
(0.17)\end{array}$ & $\begin{array}{c}0.18 \\
(0.12)\end{array}$ & $\begin{array}{l}0.086^{* *} \\
(0.043)\end{array}$ & $\begin{array}{l}0.081 \\
(0.16)\end{array}$ & $\begin{array}{c}0.14 \\
(0.11)\end{array}$ & $\begin{array}{l}0.093^{* *} \\
(0.042)\end{array}$ \\
\hline Conglomerate & $\begin{array}{l}-0.24^{*} \\
(0.14)\end{array}$ & $\begin{array}{c}0.042 \\
(0.093)\end{array}$ & $\begin{array}{l}0.016 \\
(0.051)\end{array}$ & $\begin{array}{l}-0.28^{*} \\
(0.16)\end{array}$ & $\begin{array}{c}0.067 \\
(0.086)\end{array}$ & $\begin{array}{c}0.020 \\
(0.054)\end{array}$ \\
\hline Constant & $\begin{array}{l}2.35^{* * * *} \\
(0.48)\end{array}$ & $\begin{array}{l}0.96^{* * *} \\
(0.37)\end{array}$ & $\begin{array}{l}0.24^{* *} \\
(0.12)\end{array}$ & $\begin{array}{l}2.43^{* * * *} \\
(0.55) \\
\end{array}$ & $\begin{array}{l}0.65^{*} \\
(0.36) \\
\end{array}$ & $\begin{array}{c}0.22^{* *} \\
(0.094) \\
\end{array}$ \\
\hline $\begin{array}{l}N \\
\gamma^{2}\end{array}$ & $\begin{array}{c}322 \\
4854^{* * *}\end{array}$ & $\begin{array}{c}327 \\
4187^{* * *}\end{array}$ & $\begin{array}{c}327 \\
1280^{* * * *}\end{array}$ & $\begin{array}{c}318 \\
5695^{* * *}\end{array}$ & $\begin{array}{c}323 \\
1670^{* * * *}\end{array}$ & $\begin{array}{c}323 \\
2765^{* * * *}\end{array}$ \\
\hline Overall $R^{2}$ & 0.29 & 0.18 & 0.20 & 0.29 & 0.17 & 0.18 \\
\hline
\end{tabular}


Table 4. Random effects analyses, Hypothesis 2 on majority and minority state ownership

\begin{tabular}{|c|c|c|c|c|c|c|}
\hline & $\begin{array}{c}(1) \\
\text { Tobin's } \\
\text { Q }\end{array}$ & $\begin{array}{l}\text { ( } 2)^{2} \\
\text { ROA }\end{array}$ & $\begin{array}{l}\text { (3) } \\
\text { ROS }\end{array}$ & $\begin{array}{c}(4) \\
\text { Tobin's } \\
\text { Q }\end{array}$ & $\begin{array}{c}\text { (5) } \\
\text { ROA }\end{array}$ & $\begin{array}{c}\text { (6) } \\
\text { ROS }\end{array}$ \\
\hline Foreign sales ratio & $\begin{array}{c}-0.0091 \\
(0.43)\end{array}$ & $\begin{array}{c}-0.39^{\text {***** }} \\
(0.14)\end{array}$ & $\begin{array}{l}-0.29^{* * * *} \\
(0.090)\end{array}$ & & & \\
\hline Foreign employment ratio & & & & $\begin{array}{l}-0.089 \\
(0.38)\end{array}$ & $\begin{array}{c}-0.30^{* * *} \\
(0.12)\end{array}$ & $\begin{array}{c}-0.22^{* * * *} \\
(0.060)\end{array}$ \\
\hline Majority state ownership & $\begin{array}{l}0.82^{*} \\
(0.46)\end{array}$ & $\begin{array}{l}-0.082 \\
(0.12)\end{array}$ & $\begin{array}{c}-0.18^{* * * *} \\
(0.065)\end{array}$ & $\begin{array}{l}0.73^{*} \\
(0.40)\end{array}$ & $\begin{array}{c}-0.0041 \\
(0.12)\end{array}$ & $\begin{array}{l}-0.094^{*} \\
(0.055)\end{array}$ \\
\hline Majority state ownership $\times$ Foreign sales ratio & $\begin{array}{l}0.070 \\
(0.38)\end{array}$ & $\begin{array}{l}0.35^{* * * *} \\
(0.13)\end{array}$ & $\begin{array}{l}0.31^{\text {**** }} \\
(0.082)\end{array}$ & & & \\
\hline $\begin{array}{l}\text { Majority state ownership } \times \text { Foreign employment } \\
\text { ratio }\end{array}$ & & & & $\begin{array}{c}0.43 \\
(0.33)\end{array}$ & $\begin{array}{c}0.16 \\
(0.17)\end{array}$ & $\begin{array}{l}0.23^{* * * *} \\
(0.046)\end{array}$ \\
\hline Minority state ownership & $\begin{array}{c}0.17 \\
(0.48)\end{array}$ & $\begin{array}{l}0.083 \\
(0.20)\end{array}$ & $\begin{array}{l}-0.25^{* * * *} \\
(0.092)\end{array}$ & $\begin{array}{c}0.14 \\
(0.39)\end{array}$ & $\begin{array}{l}-0.12 \\
(0.20)\end{array}$ & $\begin{array}{l}-0.13^{*} \\
(0.077)\end{array}$ \\
\hline Minority state ownership $\times$ Foreign sales ratio & $\begin{array}{c}0.14 \\
(0.63)\end{array}$ & $\begin{array}{l}-0.093 \\
(0.19)\end{array}$ & $\begin{array}{l}0.39^{* * * *} \\
(0.12)\end{array}$ & & & \\
\hline $\begin{array}{l}\text { Minority state ownership } \times \text { Foreign employment } \\
\text { ratio }\end{array}$ & & & & $\begin{array}{c}0.24 \\
(0.60)\end{array}$ & $\begin{array}{c}0.18 \\
(0.15)\end{array}$ & $\begin{array}{l}0.26^{* * *} \\
(0.099)\end{array}$ \\
\hline Foreign ownership & $\begin{array}{c}0.013 \\
(0.0089)\end{array}$ & $\begin{array}{c}0.0052^{*} \\
(0.0029)\end{array}$ & $\begin{array}{c}0.00090 \\
(0.00086)\end{array}$ & $\begin{array}{c}0.013 \\
(0.0092)\end{array}$ & $\begin{array}{c}0.0047 \\
(0.0029)\end{array}$ & $\begin{array}{c}0.0012 \\
(0.00075)\end{array}$ \\
\hline Ownership concentration & $\begin{array}{c}-0.0074^{* *} \\
(0.0035)\end{array}$ & $\begin{array}{l}0.00019 \\
(0.0024)\end{array}$ & $\begin{array}{l}-0.00053 \\
(0.00072)\end{array}$ & $\begin{array}{c}-0.0070^{* *} \\
(0.0035)\end{array}$ & $\begin{array}{l}0.00023 \\
(0.0025)\end{array}$ & $\begin{array}{l}-0.00048 \\
(0.00070)\end{array}$ \\
\hline Log of employees & $\begin{array}{c}-0.21^{* * * *} \\
(0.064)\end{array}$ & $\begin{array}{l}-0.11^{* *} \\
(0.047)\end{array}$ & $\begin{array}{l}-0.019 \\
(0.017)\end{array}$ & $\begin{array}{l}-0.21^{* *} \\
(0.082)\end{array}$ & $\begin{array}{l}-0.084^{*} \\
(0.049)\end{array}$ & $\begin{array}{l}-0.0081 \\
(0.019)\end{array}$ \\
\hline Goods & $\begin{array}{c}0.30 \\
(0.23)\end{array}$ & $\begin{array}{c}0.13 \\
(0.16)\end{array}$ & $\begin{array}{l}-0.030 \\
(0.049)\end{array}$ & $\begin{array}{c}0.30 \\
(0.23)\end{array}$ & $\begin{array}{c}0.14 \\
(0.15)\end{array}$ & $\begin{array}{l}-0.014 \\
(0.046)\end{array}$ \\
\hline Services & $\begin{array}{l}-0.21 \\
(0.22)\end{array}$ & $\begin{array}{l}-0.12 \\
(0.16)\end{array}$ & $\begin{array}{c}0.011 \\
(0.059)\end{array}$ & $\begin{array}{l}-0.23 \\
(0.24)\end{array}$ & $\begin{array}{l}-0.018 \\
(0.15)\end{array}$ & $\begin{array}{c}0.023 \\
(0.053)\end{array}$ \\
\hline Cluster & $\begin{array}{l}0.052 \\
(0.17)\end{array}$ & $\begin{array}{c}0.14 \\
(0.10)\end{array}$ & $\begin{array}{l}0.083^{\text {*** }} \\
(0.040)\end{array}$ & $\begin{array}{l}0.043 \\
(0.16)\end{array}$ & $\begin{array}{c}0.11 \\
(0.099)\end{array}$ & $\begin{array}{l}0.081^{* * *} \\
(0.036)\end{array}$ \\
\hline Conglomerate & $\begin{array}{l}-0.25 \\
(0.16)\end{array}$ & $\begin{array}{c}0.067 \\
(0.092)\end{array}$ & $\begin{array}{c}0.013 \\
(0.054)\end{array}$ & $\begin{array}{l}-0.24 \\
(0.19)\end{array}$ & $\begin{array}{c}0.066 \\
(0.091)\end{array}$ & $\begin{array}{l}0.0098 \\
(0.057)\end{array}$ \\
\hline Constant & $\begin{array}{c}2.43^{* * * *} \\
(0.55) \\
\end{array}$ & $\begin{array}{c}0.89^{* * * *} \\
(0.32)\end{array}$ & $\begin{array}{l}0.39^{* * * *} \\
(0.13)\end{array}$ & $\begin{array}{l}2.45^{* * * *} \\
(0.60) \\
\end{array}$ & $\begin{array}{l}0.64^{*} \\
(0.34)\end{array}$ & $\begin{array}{c}0.20^{* * *} \\
(0.094)\end{array}$ \\
\hline$N_{2}$ & 322 & 327 & 327 & 318 & 323 & 323 \\
\hline$\chi^{2}$ & $601.3^{* * *}$ & $486.8^{* * *}$ & $1095.6^{* * *}$ & $351.2^{* * *}$ & $311.6^{* * *}$ & $2256.3^{* * *}$ \\
\hline Overall $R^{2}$ & 0.31 & 0.13 & 0.22 & 0.31 & 0.12 & 0.23 \\
\hline
\end{tabular}


Table 5. Random effects analyses, Hypothesis 3 on origins of SOEs in administration or otherwise

\begin{tabular}{|c|c|c|c|c|c|c|}
\hline & $\begin{array}{l}\text { (1) } \\
\text { Tobin's } \\
\text { Q }\end{array}$ & $\begin{array}{c}\text { (2) } \\
\text { ROA }\end{array}$ & $\begin{array}{c}(3) \\
\text { ROS }\end{array}$ & $\begin{array}{c}(4) \\
\text { Tobin's } \\
\text { Q }\end{array}$ & $\begin{array}{c}5) \\
\text { ROA }\end{array}$ & $\begin{array}{c}6) \\
\text { ROS }\end{array}$ \\
\hline Foreign sales ratio & $\begin{array}{c}0.12 \\
(0.48)\end{array}$ & $\begin{array}{c}-0.41^{* * * *} \\
(0.13)\end{array}$ & $\begin{array}{l}-0.27^{\text {**** }} \\
(0.091)\end{array}$ & & & \\
\hline Foreign employment ratio & & & & $\begin{array}{l}-0.013 \\
(0.38)\end{array}$ & $\begin{array}{c}-0.28^{* * *} \\
(0.11)\end{array}$ & $\begin{array}{c}-0.21^{* * * *} \\
(0.054)\end{array}$ \\
\hline Previous state administration & $\begin{array}{c}0.75 \\
(0.55)\end{array}$ & $\begin{array}{l}-0.042 \\
(0.17)\end{array}$ & $\begin{array}{l}-0.14^{*} \\
(0.079)\end{array}$ & $\begin{array}{c}0.78 \\
(0.49)\end{array}$ & $\begin{array}{c}-0.0025 \\
(0.18)\end{array}$ & $\begin{array}{l}-0.082 \\
(0.090)\end{array}$ \\
\hline Previous state administration $\times$ Foreign sales ratio & $\begin{array}{l}-0.12 \\
(0.50)\end{array}$ & $\begin{array}{c}0.34^{* * * *} \\
(0.12)\end{array}$ & $\begin{array}{l}0.29^{* * * *} \\
(0.093)\end{array}$ & & & \\
\hline $\begin{array}{l}\text { Previous state administration } \times \text { Foreign } \\
\text { employment ratio }\end{array}$ & & & & $\begin{array}{l}-0.25 \\
(0.64)\end{array}$ & $\begin{array}{l}0.29 \\
(0.19)\end{array}$ & $\begin{array}{l}0.23^{* *} \\
(0.10)\end{array}$ \\
\hline Non previous state administration & $\begin{array}{c}0.41 \\
(0.37)\end{array}$ & $\begin{array}{l}0.014 \\
(0.16)\end{array}$ & $\begin{array}{c}-0.22^{* * * *} \\
(0.074)\end{array}$ & $\begin{array}{c}0.30 \\
(0.31)\end{array}$ & $\begin{array}{l}-0.071 \\
(0.16)\end{array}$ & $\begin{array}{l}-0.12^{* *} \\
(0.057)\end{array}$ \\
\hline $\begin{array}{l}\text { Non previous state administration } \times \text { Foreign sales } \\
\text { ratio }\end{array}$ & $\begin{array}{l}-0.11 \\
(0.51)\end{array}$ & $\begin{array}{l}-0.014 \\
(0.17)\end{array}$ & $\begin{array}{l}0.36^{* * * *} \\
(0.10)\end{array}$ & & & \\
\hline $\begin{array}{l}\text { Non previous state administration } \times \text { Foreign } \\
\text { employment ratio }\end{array}$ & & & & $\begin{array}{l}0.054 \\
(0.50)\end{array}$ & $\begin{array}{l}0.097 \\
(0.13)\end{array}$ & $\begin{array}{l}0.24^{* * * *} \\
(0.075)\end{array}$ \\
\hline Foreign ownership & $\begin{array}{c}0.012 \\
(0.0083)\end{array}$ & $\begin{array}{l}0.0053^{* *} \\
(0.0027)\end{array}$ & $\begin{array}{c}0.00086 \\
(0.00080)\end{array}$ & $\begin{array}{c}0.012 \\
(0.0086)\end{array}$ & $\begin{array}{c}0.0044^{*} \\
(0.0025)\end{array}$ & $\begin{array}{c}0.0012^{*} \\
(0.00066)\end{array}$ \\
\hline Ownership concentration & $\begin{array}{l}-0.0065^{* * *} \\
(0.0029)\end{array}$ & $\begin{array}{l}0.00013 \\
(0.0025)\end{array}$ & $\begin{array}{l}-0.00048 \\
(0.00070)\end{array}$ & $\begin{array}{l}-0.0065^{* * *} \\
(0.0031)\end{array}$ & $\begin{array}{l}0.00018 \\
(0.0026)\end{array}$ & $\begin{array}{l}-0.00047 \\
(0.00067)\end{array}$ \\
\hline Log of employees & $\begin{array}{c}-0.20^{* * * *} \\
(0.063)\end{array}$ & $\begin{array}{l}-0.11^{* * *} \\
(0.047)\end{array}$ & $\begin{array}{l}-0.021 \\
(0.016)\end{array}$ & $\begin{array}{l}-0.20^{* *} \\
(0.081)\end{array}$ & $\begin{array}{l}-0.089^{*} \\
(0.050)\end{array}$ & $\begin{array}{c}-0.0089 \\
(0.018)\end{array}$ \\
\hline Goods & $\begin{array}{c}0.18 \\
(0.18)\end{array}$ & $\begin{array}{c}0.14 \\
(0.16)\end{array}$ & $\begin{array}{l}-0.041 \\
(0.048)\end{array}$ & $\begin{array}{c}0.17 \\
(0.18)\end{array}$ & $\begin{array}{c}0.12 \\
(0.14)\end{array}$ & $\begin{array}{l}-0.020 \\
(0.046)\end{array}$ \\
\hline Services & $\begin{array}{l}-0.30 \\
(0.25)\end{array}$ & $\begin{array}{l}-0.092 \\
(0.16)\end{array}$ & $\begin{array}{l}0.0039 \\
(0.056)\end{array}$ & $\begin{array}{l}-0.30 \\
(0.26)\end{array}$ & $\begin{array}{l}-0.019 \\
(0.15)\end{array}$ & $\begin{array}{c}0.020 \\
(0.053)\end{array}$ \\
\hline Cluster & $\begin{array}{l}0.047 \\
(0.18)\end{array}$ & $\begin{array}{c}0.15 \\
(0.11)\end{array}$ & $\begin{array}{l}0.075^{*} \\
(0.041)\end{array}$ & $\begin{array}{l}0.043 \\
(0.16)\end{array}$ & $\begin{array}{c}0.099 \\
(0.093)\end{array}$ & $\begin{array}{l}0.077^{* *} \\
(0.037)\end{array}$ \\
\hline Conglomerate & $\begin{array}{l}-0.22 \\
(0.16)\end{array}$ & $\begin{array}{c}0.067 \\
(0.096)\end{array}$ & $\begin{array}{c}0.015 \\
(0.052)\end{array}$ & $\begin{array}{l}-0.24 \\
(0.17)\end{array}$ & $\begin{array}{c}0.078 \\
(0.089)\end{array}$ & $\begin{array}{c}0.012 \\
(0.056)\end{array}$ \\
\hline Constant & $\begin{array}{l}2.29^{* * * *} \\
(0.49)\end{array}$ & $\begin{array}{l}0.91^{* * * *} \\
(0.34)\end{array}$ & $\begin{array}{c}0.40^{* * * * *} \\
(0.13)\end{array}$ & $\begin{array}{c}2.38^{* * * *} \\
(0.59)\end{array}$ & $\begin{array}{c}0.68^{*} \\
(0.35)\end{array}$ & $\begin{array}{c}0.20^{* * *} \\
(0.094)\end{array}$ \\
\hline $\begin{array}{l}N \\
\chi^{2} \\
\text { Overall } R^{2}\end{array}$ & $\begin{array}{c}322 \\
741.0^{* * *} \\
0.31\end{array}$ & $\begin{array}{c}327 \\
506.5^{* * *} \\
0.12\end{array}$ & $\begin{array}{c}327 \\
126.8^{* * * *} \\
0.23\end{array}$ & $\begin{array}{c}318 \\
507.6^{* * * *} \\
0.31\end{array}$ & $\begin{array}{c}323 \\
316.1^{* * *} \\
0.12\end{array}$ & $\begin{array}{c}323 \\
1758.5^{* * * *} \\
0.22\end{array}$ \\
\hline
\end{tabular}




\section{APPENDIX}

Table A1. Average marginal effects; $p$-values in parentheses

\begin{tabular}{|c|c|c|c|c|c|c|}
\hline $\begin{array}{c}\text { State } \\
\text { ownership \% }\end{array}$ & $\begin{array}{l}\text { Model 1: } \\
\text { Tobin's Q, } \\
\text { FSTS }\end{array}$ & $\begin{array}{l}\text { Model 2: } \\
\text { ROA, } \\
\text { FSTS }\end{array}$ & $\begin{array}{l}\text { Model 3: } \\
\text { ROS, } \\
\text { FSTS }\end{array}$ & $\begin{array}{l}\text { Model 4: } \\
\text { Tobin's Q, } \\
\text { FETE }\end{array}$ & $\begin{array}{l}\text { Model 5: } \\
\text { ROA, } \\
\text { FETE }\end{array}$ & $\begin{array}{l}\text { Model 6: } \\
\text { ROS, } \\
\text { FETE }\end{array}$ \\
\hline \multirow[t]{2}{*}{0} & 0.0994 & -0.5079 & -0.0658 & -0.0402 & -0.2402 & -0.1394 \\
\hline & $(0.787)$ & $(0.000)$ & $(0.520)$ & $(0.900)$ & $(0.001)$ & $(0.003)$ \\
\hline \multirow[t]{2}{*}{10} & 0.0680 & -0.4390 & -0.0447 & -0.0925 & -0.2011 & -0.1038 \\
\hline & $(0.820)$ & $(0.001)$ & $(0.616)$ & $(0.722)$ & $(0.004)$ & $(0.013)$ \\
\hline \multirow[t]{2}{*}{20} & 0.0365 & -0.3702 & -0.0235 & -0.1448 & -0.1620 & -0.068 \\
\hline & $(0.877)$ & $(0.002)$ & $(0.758)$ & $(0.578)$ & $(0.032)$ & $(0.090)$ \\
\hline \multirow[t]{2}{*}{30} & 0.0050 & -0.3013 & -0.0023 & -0.1971 & -0.1229 & -0.0325 \\
\hline & $(0.978)$ & $(0.007)$ & $(0.971)$ & $(0.541)$ & $(0.174)$ & $(0.452)$ \\
\hline \multirow[t]{2}{*}{40} & -0.0265 & -0.2325 & 0.0188 & -0.2494 & -0.0839 & 0.0032 \\
\hline & $(0.864)$ & $(0.025)$ & $(0.733)$ & $(0.552)$ & $(0.448)$ & $(0.949)$ \\
\hline \multirow[t]{2}{*}{50} & -0.0580 & -0.1637 & 0.0400 & -0.3016 & -0.0448 & 0.0388 \\
\hline & $(0.718)$ & $(0.090)$ & $(0.408)$ & $(0.571)$ & $(0.738)$ & $(0.510)$ \\
\hline \multirow[t]{2}{*}{60} & -0.0895 & -0.0948 & 0.0611 & -0.3540 & -0.0057 & 0.0744 \\
\hline & $(0.654)$ & $(0.297)$ & $(0.183)$ & $(0.588)$ & $(0.971)$ & $(0.284)$ \\
\hline \multirow[t]{2}{*}{70} & -0.1210 & -0.0260 & 0.0823 & -0.4062 & 0.0333 & 0.1101 \\
\hline & $(0.637)$ & $(0.767)$ & $(0.089)$ & $(0.602)$ & $(0.856)$ & $(0.174)$ \\
\hline \multirow[t]{2}{*}{80} & -0.1525 & 0.0429 & 0.1035 & -0.4585 & 0.0724 & 0.1457 \\
\hline & $(0.636)$ & $(0.620)$ & $(0.060)$ & $(0.613)$ & $(0.731)$ & $(0.118)$ \\
\hline \multirow[t]{2}{*}{90} & -0.1839 & 0.1117 & 0.1246 & -0.5108 & 0.1115 & 0.18149 \\
\hline & $(0.639)$ & $(0.202)$ & $(0.054)$ & $(0.621)$ & $(0.639)$ & $(0.086)$ \\
\hline \multirow[t]{2}{*}{100} & -0.2154 & 0.1806 & 0.1458 & -0.5631 & 0.1505 & 0.2170 \\
\hline & $(0.642)$ & $(0.047)$ & $(0.056)$ & $(0.629)$ & $(0.569)$ & $(0.067)$ \\
\hline
\end{tabular}

This article is protected by copyright. All rights reserved. 